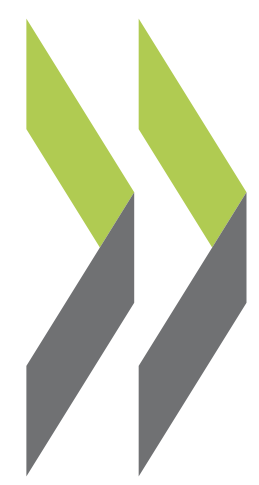

OECD Social, Employment and Migration Working Papers No. 80

Main Features of the Public Employment Service

\title{
Daniela Kalužná
} in Poland 
Organisation de Coopération et de Développement Économiques

Organisation for Economic Co-operation and Development

20-Mar-2009

DIRECTORATE FOR EMPLOYMENT, LABOUR AND SOCIAL AFFAIRS

English - Or. English EMPLOYMENT, LABOUR AND SOCIAL AFFAIRS COMMITTEE

OECD SOCIAL, EMPLOYMENT AND MIGRATION PAPERS NO. 80

MAIN FEATURES OF THE PUBLIC EMPLOYMENT SERVICE IN POLAND

Daniela Kalužná

JEL codes for classification: H53, H83, I38, J08, J63 and J65

JT03261602

Document complet disponible sur OLIS dans son format d'origine

Complete document available on OLIS in its original format 


\title{
DIRECTORATE FOR EMPLOYMENT, LABOUR AND SOCIAL AFFAIRS
}

http://www.oecd.org/els

\section{OECD SOCIAL, EMPLOYMENT AND MIGRATION WORKING PAPERS}

\author{
http://www.oecd.org/els/workingpapers
}

This series is designed to make available to a wider readership selected labour market, social policy and migration studies prepared for use within the OECD. Authorship is usually collective, but principal writers are named. The papers are generally available only in their original language - English or French - with a summary in the other.

Comment on the series is welcome, and should be sent to the Directorate for Employment, Labour and Social Affairs, 2, rue André-Pascal, 75775 PARIS CEDEX 16, France.

The opinions expressed and arguments employed here are the responsibility of the author(s) and do not necessarily reflect those of the OECD

\author{
Applications for permission to reproduce or translate \\ all or part of this material should be made to: \\ Head of Publications Service \\ OECD \\ 2, rue André-Pascal \\ 75775 Paris, CEDEX 16 \\ France
}

Copyright OECD 2009 


\section{ACKNOWLEDGEMENTS}

This report has been prepared by Daniela Kalužná, consultant, as background for the OECD Review of Activation Policies. In addition to written documentation, it is based on an interview and informationgathering visit to Poland in January 2008 and continuing contacts with some officials through to October 2008. Warm thanks are extended to all people who provided this assistance and advice. The author is especially grateful to Iwona Trzcińska, Elżbieta Pernak, Ewa Chylek, Andrzej Trzeciecki, Krzystof Kaczmarek and Magdalena Nojszewska for helpful interviews and Małgorzata Sarzalska for clarifications of statistical data, and to the Polish authorities for their detailed reading of the draft report and corresponding official comments and suggestions. Special thanks are extended to OECD staff David Grubb for extremely useful guidance, comments and editing, and Sylvie Cimper for further editing assistance. The views expressed remain those of the author, and do not necessarily represent those of the OECD or its member governments. 
DELSA/ELSA/WD/SEM(2009)8 


\section{SUMMARY}

This report describes the organisation of employment services, labour market programmes, unemployment insurance (UI) benefits and social assistance in Poland according to the legislation that was in force until January 2009, when the Act on employment promotion and labour market institutions was amended.

The decentralisation of employment service began in 1998 and was completed in 2002. Since decentralisation, local-level poviat labour offices (PUP) report to local mayors (starosta or prezydent miasta na prawach powiatu). However, state structures at a regional level supervise the performance of both the PUP and, at the regional level, the voivodeship labour offices (WUP). These offices must follow some centrally-defined rules and legal standards: for example, a Ministerial guideline in 2007 defined minimum numbers of staff they should employ by main function. However, their operational costs are in principle borne by the respective territorial levels of government. Under-financing is common, and there are concerns that decentralisation has led to more uneven service provision and performance. Local budgets may be used to finance the outsourcing of some PUP labour market services, but local authorities usually find that in-house provision is cheaper.

Not including programme specialists or managers, only $18.6 \%$ of PUP staff are front-line officers, well below the shares in the Slovak Republic (29\%) or the Czech Republic (23\%). In 2006 there were on average 1132 registered unemployed per placement officer. In 2004 and 2005, the PUP hired unemployed people on subsidised short-term contracts, and annual staff turnover was as high as $60 \%$. For such reasons, public job-broking has a poor reputation.

Employers are legally obliged to notify vacancies to the PUP, but in practice employers mainly notify vacancies for low-skilled jobs. In 2008 placement officers had no access to the job vacancy databases of the other PUP, although more recently a national vacancy database has become operational. In 2006, Warsaw PUP assisted $84 \%$ of all exits to employment, which represented $37 \%$ of total outflows from its unemployment register, and it assisted in filling $77.1 \%$ of notified job offers. If this percentage is applied to all job offers notified in Poland, the market share of the PES in all job hires can be estimated as $22 \%$.

Labour market programmes are financed by Labour Fund, the state budget, local government budgets and European structural funds. However, the programmes and their target groups are mainly defined by law at central level. Performance management is not very sophisticated: the central government monitors the immediate outputs such as number of entries into work, a focus which may conflict with the priorities of local actors. The Labour Fund (LF) also finances unemployment insurance (UI) benefits. In 2006, its active spending increased by $51 \%$ due to a large increase for services provided by local PES institutions, and in 2007 its active spending exceeded passive spending for the first time.

For entitlement to UI benefits, the claimant must have worked at least 12 months out of the last 18 months. Benefit periods differ across the country, depending on the unemployment rate in the region of residence and specific periods are defined for some groups of unemployed. This arrangement has encouraged some people to move to regions where unemployment is higher. In 2007 the basic benefit amount was $19 \%$ of the average wage and $49 \%$ of the statutory minimum wage. When they find work through individual job search, the unemployed are granted an activation allowance: the number of grants dropped from 105900 in 2005 to 88200 in 2006 because the amount of the allowance was reduced and UI beneficiaries were less motivated to start work before exhaustion of their entitlement. 
UI beneficiaries must be available for full-time work ( 40 hours per week) or participation in a labour market programme, subject to their health condition. Enforcement of the availability requirement is locally variable. Some PUP are quite strict, but appeal institutions often revoke PUP decisions to impose sanctions for inappropriate behaviour, and the PUP have virtually no possibility of verifying the legitimacy of medical certificates.

UI benefit coverage is low, while at the same time almost $85 \%$ of the recipients of temporary social assistance benefits in 2004 were unemployed. Social assistance in Poland is delivered at the gmina (communal) level by social assistance centres (OPS). In 2006, for each social worker there were on average 156 main recipients and 302 persons in families, of whom 31 were considered employable (with a also second employable person in the family, in some cases). According to legislation, the OPS should have at least 1 social worker for each 2000 inhabitants. Many of them fail to comply with this norm due to local budget constraints, but the client/staff ratios remain much more favourable than they are for the PUP.

Until recently, gminas could refuse income support for a family on grounds of lack of resources. In 2004, the central government introduced subsidies to finance the guaranteed part of temporary benefits. The average amount paid has increased, but it remains very low, although for large families it may nevertheless become quite high in relation to the minimum wage. Gmina councils can top-up the amounts, but most of them are not enthusiastic about investing their own funds. Social workers may cut or stop the benefit due to insufficient co-operation on the side of the beneficiary, but they rarely do so. Usually they try to grant income support on other grounds listed in the legislation, especially when families with children are concerned. Social workers are somewhat discouraged from making sanction decisions because they tend to be overturned by gmina appeal bodies.

In general the PUP focus their attention on UI beneficiaries, who are required to come to the PUP every month, while other registered unemployed only come once every three months, although practices vary. The majority of the PUP do not notify their clients about suitable job offers or training possibilities between personal visits. Many of the clients who are "just registered" are not seeking a job and should not be counted as unemployed: but at the same time, in principle activation requirements should be extended to recipients of social-safety-net benefits. Co-operation between the OPS and the PUP is rather weak, which is perceived as a problem more by social workers than the PUP staff.

From 2004, social workers may set up a contract with social assistance beneficiaries, similar to the individual action plans used by the employment service, but in 2006 only $2 \%$ had one. Social workers mainly focus on social activation, which precedes activation for work and may take from 2 to 12 months, depending on individual circumstances and the scale of the problem. Beneficiaries are then asked to register with a PUP or are referred to social integration centres (CIS) or social integration clubs (KIS). The OPS often run job clubs, sometimes in co-operation with the PUP.

The CIS, which were introduced in 2004 then rapidly expanded in number, provide social employment together with social counselling and occupational training. Participants generally have serious reintegration problems, but they must be employable and prove high levels of commitment. Participation is normally for 12 months for a minimum of six hours daily. In return, participants receive income support at the level of the UI benefit. This intensive treatment, based on a mutual obligations approach, seems to give good results, since $52 \%$ of those who acquired qualifications in CIS and $42 \%$ of those who did not were employed when their CIS attendance finished. However, further analysis of the sustainability of the outcomes and the cost-effectiveness of the CIS approach, particularly the supported forms of employment, is desirable. 


\section{RÉSUMÉ}

Le présent rapport décrit l'organisation des services de l'emploi, des programmes du marché du travail, des allocations d'assurance-chômage et de l'aide sociale en Pologne, selon la législation en vigueur jusqu'en janvier 2009, date de révision de la Loi sur la promotion de l'emploi et des institutions du marché du travail.

La décentralisation des services de l'emploi a commencé en 1998 et s'est achevée en 2002. Les poviats, agences pour l'emploi au niveau local (PUP), sont désormais placées sous la tutelle du maire (starosta ou prezydent miasta na prawach powiatu), tandis que les voïvodies, agences pour l'emploi à l'échelon régional (WUP), supervisent aussi les performances des PUP et des WUP, qui doivent se conformer à des normes définies par l'administration centrale : ainsi, en 2007, une directive ministérielle stipulait l'effectif minimum de ces agences par principale fonction. En revanche, leurs dépenses de fonctionnement sont, en principe, prises en charge par les collectivités territoriales. Les problèmes de financement sont fréquents et certains estiment que la décentralisation a accentué les déséquilibres géographiques au niveau de l'offre et de la qualité des services. Les budgets des collectivités locales peuvent servir à financer la sous-traitance de certaines fonctions des PUP, mais les autorités locales considèrent généralement qu'il est moins coûteux de fournir ces services en interne.

En dehors des spécialistes ou responsables des programmes, seuls $18.6 \%$ des effectifs des PUP sont des agents qui travaillent "en première ligne », ce qui est bien en deçà de la moyenne en République slovaque (29\%) et en République tchèque (23\%). En 2006, on comptait en moyenne 1132 chômeurs inscrits par placeur. En 2004 et 2005, les PUP embauchaient des chômeurs grâce à des contrats à court terme subventionnés, et le taux annuel de rotation des effectifs atteignait $60 \%$. Pour de telles raisons le service public de l'emploi a mauvaise réputation.

Si la loi contraint les employeurs à informer les PUP des postes vacants, dans la pratique, ils signalent principalement les offres pour les emplois les moins qualifiés. En 2008, les agents des PUP n'avaient pas accès aux bases de données relatives aux vacances d'emplois des autres agences, mais récemment une base de données nationale est devenue opérationnelle. En 2006, le PUP de Varsovie a contribué à $84 \%$ des reprises d'activité, ce qui correspond à $37 \%$ du total des sorties de la liste des demandeurs d'emploi. Il a en outre contribué à satisfaire $77.1 \%$ des offres d'emploi notifiées. En appliquant ce pourcentage à l'ensemble des offres d'emploi notifiées en Pologne, la part de marché du service public de l'emploi dans l'ensemble des embauches est estimée à $22 \%$.

Les programmes du marché du travail sont financés par le Fonds pour l'emploi, le budget de l'État, les budgets des administrations locales et les fonds structurels européens. Néanmoins, ces programmes et leurs groupes cibles sont principalement définis par l'administration centrale. La procédure de gestion des performances est relativement simple : l'administration centrale contrôle les résultats immédiats comme le nombre de reprises d'activité, une stratégie qui peut aller à l'encontre des priorités des intervenants locaux. Le Fonds pour 1'emploi finance également les allocations d'assurance-chômage. En 2006, ses dépenses actives ont augmenté de $51 \%$ sous l'effet de la hausse substantielle accordée pour les services fournis par les services publics de l'emploi au niveau local, et en 2007 ses dépenses actives ont surpassé, pour la première fois, ses dépenses passives. 
Pour percevoir les allocations d'assurance-chômage, le demandeur d'emploi doit avoir travaillé au minimum 12 mois sur les 18 derniers mois. Les durées de prestations varient en fonction des régions et dépendent du taux de chômage dans la région de résidence; des durées spécifiques sont définies pour quelques groupes de chômeurs. Ce dispositif a incité certaines personnes à s'installer dans des régions où le taux de chômage est plus élevé. En 2007, le montant de l'allocation de base s'élevait à 19 \% du salaire moyen et à $49 \%$ du salaire minimum légal. S'ils trouvent un emploi par leurs propres moyens, les chômeurs perçoivent une prime d' "activation » : le nombre des primes accordées a diminué de 105900 en 2005 à 88200 en 2006 suite à la baisse du montant des primes, qui a pesé sur la motivation des bénéficiaires de la prime à retrouver un emploi avant la fin de leurs droits.

Les bénéficiaires de l'assurance-chômage doivent être disponibles pour un travail à temps complet (40 heures hebdomadaires) ou pour participer à l'un des programmes du marché du travail, en fonction de leur état de santé. L'application du critère relatif à la disponibilité varie entre les régions : si certaines PUP sont relativement strictes, les commissions de recours invalident souvent leurs décisions d'imposer des sanctions pour comportement inapproprié et les PUP n'ont quasiment aucune possibilité de vérifier la légitimité des certificats médicaux.

Le niveau de couverture de l'assurance-chômage est limité, alors que presque $85 \%$ des bénéficiaires d'un complément de revenu du système d'aide sociale en 2004 étaient des demandeurs d'emploi. En Pologne, l'aide sociale est fournie au niveau des gminas (les communes) par des centres d'aide sociale (OPS). En 2006, on comptait en moyenne 156 bénéficiaires pour chaque travailleur social, dont 31 étaient considérés comme aptes à l'emploi (avec dans certains cas une deuxième personne apte à l'emploi au sein du foyer). Selon la loi, les OPS devraient compter au minimum 1 travailleur social pour 2000 habitants. De nombreux centres ne sont pas en mesure de respecter cette norme en raison des contraintes budgétaires locales, mais les ratios clients/personnel restent bien plus favorables que ceux des PUP.

Récemment encore, les gminas pouvaient refuser d'octroyer une aide aux familles en invoquant des ressources insuffisantes. En 2004, l'administration centrale a instauré des subventions afin de financer la partie garantie des prestations temporaires. Le montant moyen des allocations versées a augmenté mais reste très faible, même si pour les grandes familles il peut devenir assez élevé par rapport au salaire minimum. Les gminas ont la possibilité de compléter ces aides mais la plupart sont réticentes à l'idée d'investir leurs propres ressources. Les travailleurs sociaux peuvent réduire ou supprimer les allocations s'ils estiment que le bénéficiaire ne coopère pas assez, mais ils le font rarement. En règle générale, ils essaient d'accorder des aides en s'appuyant sur d'autres critères énoncés par la loi, particulièrement pour les familles avec enfants en difficulté. Les travailleurs sociaux sont quelque peu découragés de prendre des sanctions dans la mesure où les commissions de recours des gminas tendent à annuler leurs décisions.

En général, les PUP concentrent leur attention sur les bénéficiaires des allocations d'assurancechômage, qui sont tenus de se rendre dans leur agence une fois par mois, alors que les autres demandeurs d'emploi inscrits ne doivent se présenter qu'une fois tous les trois mois, même si les pratiques varient. La majorité des PUP n'informent pas leurs clients des offres d'emploi intéressantes ni des possibilités de formation dans l'intervalle entre deux visites. De nombreux demandeurs d'emploi qui sont «simplement inscrits » ne recherchent pas activement un emploi et ne devraient pas être comptabilisés parmi les chômeurs : néanmoins, en principe, l'obligation pour les chômeurs d'accepter un emploi subventionné ou une formation devrait être appliquée également aux bénéficiaires de l'aide sociale. Les centres d'aide sociale et les PUP coopèrent peu, ce qui est perçu comme un problème davantage par les travailleurs sociaux que par le personnel des PUP.

Depuis 2004, les travailleurs sociaux peuvent établir un contrat avec les bénéficiaires de l'aide sociale, à l'image des projets personnalisés d'accès à l'emploi. Toutefois, en 2006, seuls $2 \%$ des bénéficiaires avaient conclu ce type de contrat. Les travailleurs sociaux ciblent en premier lieu l'activation 
sociale qui précède le retour à l'emploi et peut prendre de 2 à 12 mois, en fonction de la situation individuelle et de l'ampleur du problème. Les bénéficiaires de l'aide sociale sont ensuite invités à s'inscrire auprès d'un PUP ou, dans certains cas, sont dirigés vers des centres pour l'intégration sociale (CIS) ou des clubs pour l'intégration sociale (KIS). Les centres d'aide sociale proposent souvent des clubs pour l'emploi, parfois en coopération avec les PUP.

Les CIS, créés en 2004 qui ont connu une expansion rapide en nombre, proposent des emplois sociaux et fournissent des conseils et des formations professionnelles. Les participants rencontrent généralement de sérieuses difficultés d'intégration, mais doivent être aptes à l'emploi et faire preuve d'une forte motivation. Ils s'engagent généralement à participer pour une durée de 12 mois, sur la base de six heures quotidiennes minimum, en échange de quoi ils perçoivent une aide au revenu équivalente à l'allocation d'assurance-chômage. Ce programme intensif, fondé sur des obligations réciproques, semble fournir de bons résultats, puisque $52 \%$ des participants qui ont acquis une qualification au sein d'un CIS et $42 \%$ de ceux qui n'en ont pas acquis, occupaient un emploi à l'issue de leur programme au sein du CIS. Cependant, il convient de recueillir davantage d'informations sur la pérennité de ces résultats et sur le rapport coût-efficacité des CIS, notamment dans le cas des emplois subventionnés. 


\section{TABLE OF CONTENTS}

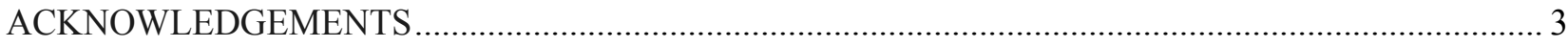

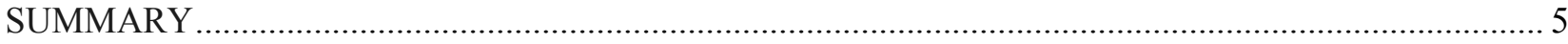

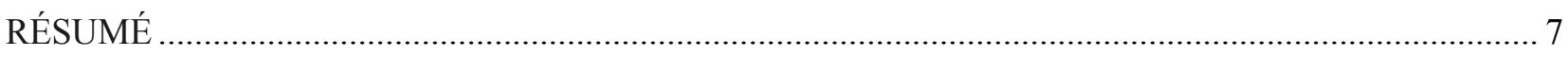

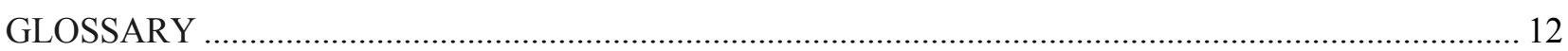

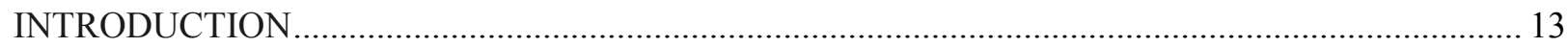

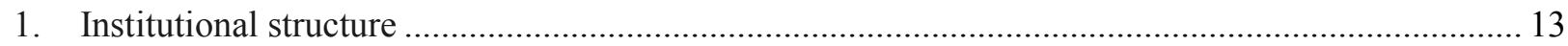

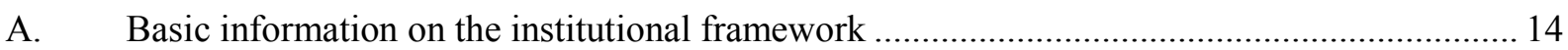

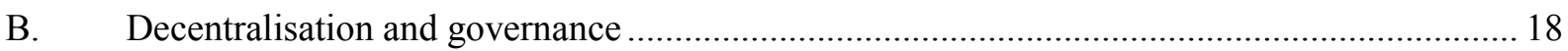

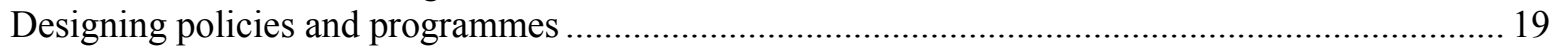

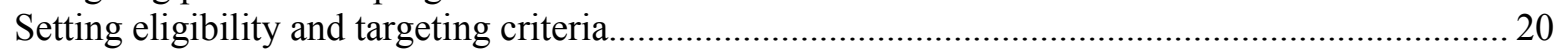

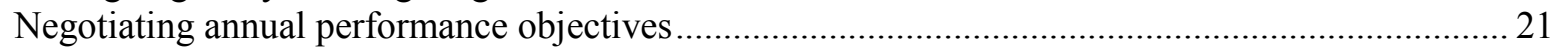

Developing and maintaining relationships with other labour market actors................................... 21

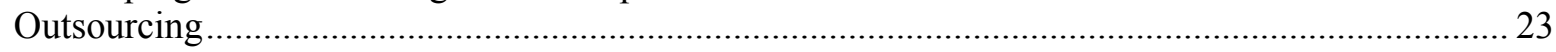

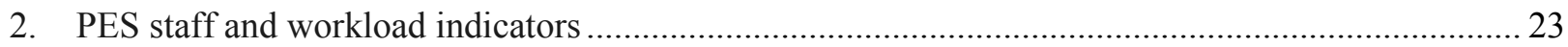

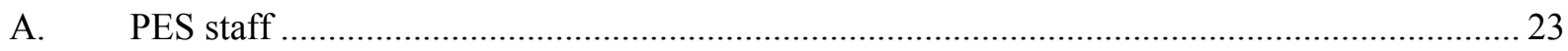

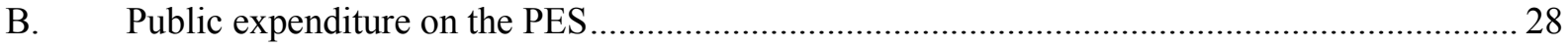

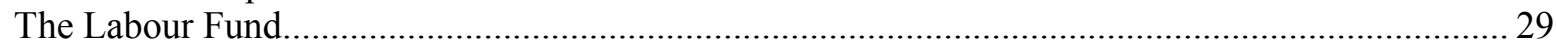

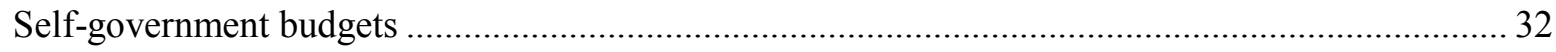

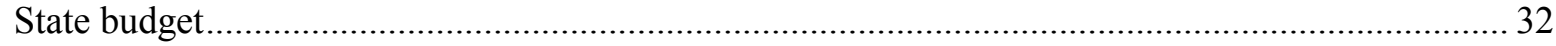

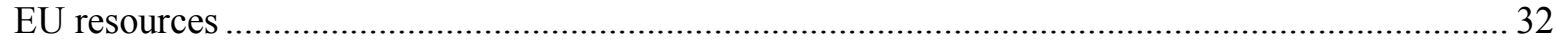

Public expenditure on public employment service and administration............................................. 32

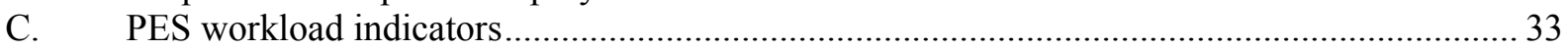

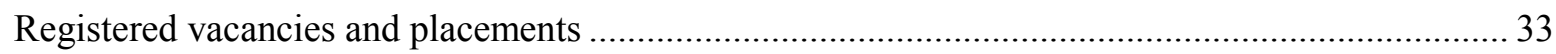

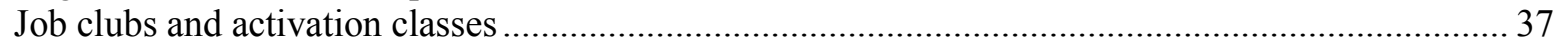

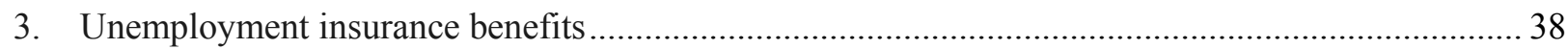

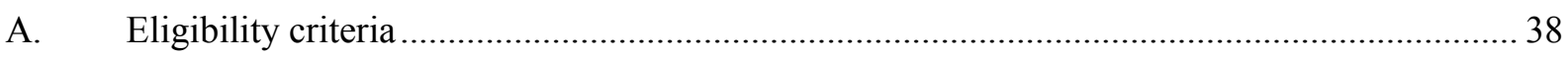

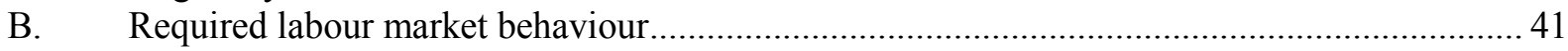

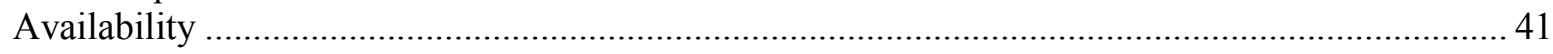

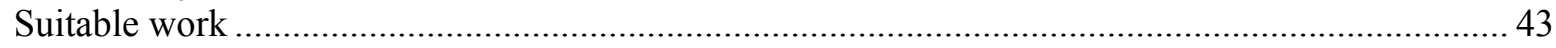

4. Approaches to the activation of beneficiaries of social-safety-net benefits..................................... 45

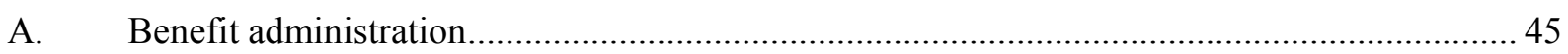

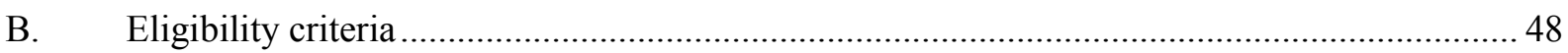

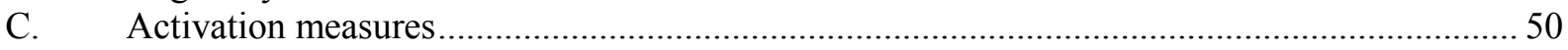

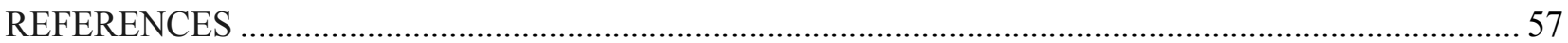

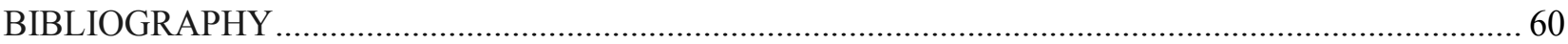




\section{List of Boxes}

Box 1. Active labour market programmes in Poland 16

Box 2.

Box 3.

The system of allocations from the Labour Fund .

Box 4.

Job clubs in Poland

\section{List of Tables}

Table 1. State budget transfers to poviat and voivodeship labour offices, 2000-2005 .................. 15

Table 2. $\quad$ Participants in active labour market programmes, 2006 ................................................ 18

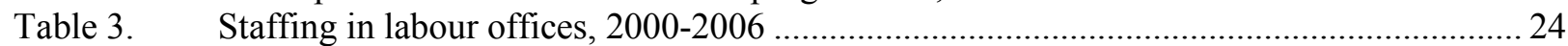

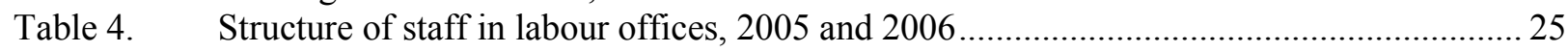

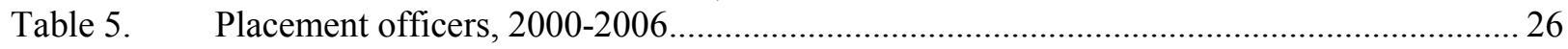

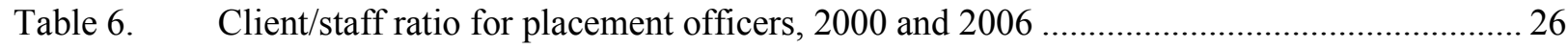

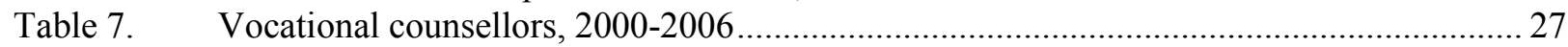

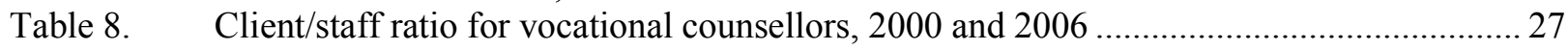

Table 9. $\quad$ Staff separations from poviat and voivodeship labour offices

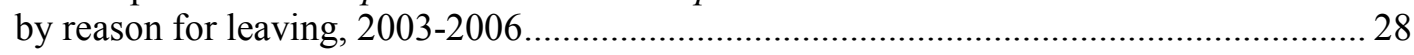

Table 10. Labour Fund revenues, 2006-2008 .............................................................................. 29

Table 11. Structure of planned expenditure from the Labour Fund, 2006-2008 ................................ 31

Table 12. Structure of planned expenditure from the Labour Fund on active programmes

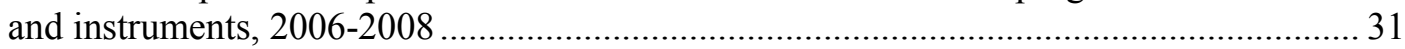

Table 13. Public expenditure on PES and administration functions, 2005 and 2006........................ 33

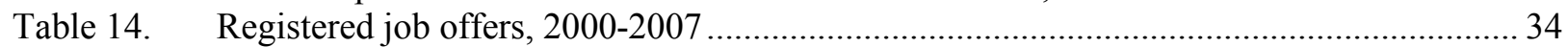

Table 15. Notified job offers and job offers unfilled for more than a month, 2001-2007 ................ 35

Table 16. Outflows from the unemployment registry to work, 2000-2007....................................... 36

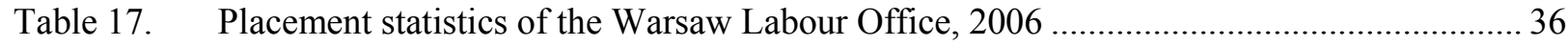

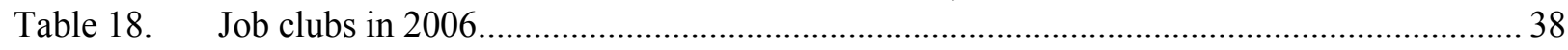

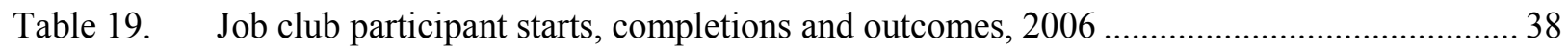

Table 20. Number of unemployment and pre-retirements benefits in payment, 2001-2006............. 40

Table 21. Unemployment insurance coverage of registered unemployment, 2000-2007 ................. 42

Table 22. Social assistance centres by number of staff, 2006 ................................................. 46

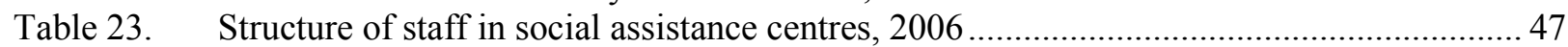

Table 24. Types of social assistance benefits granted, 2000-2006 _................................................... 49

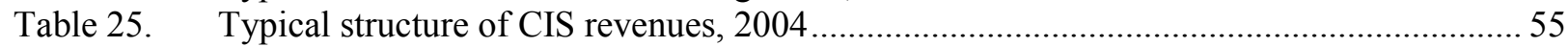

Table 26. Labour force status of CIS participants after programme completion, 2006 .................... 56 


\section{GLOSSARY}

\begin{tabular}{|c|c|c|}
\hline CIS & Social integration centre & Centrum Integracji Społecznej \\
\hline ESF & European Social Fund & Europejski Fundusz Spoleczny \\
\hline EURES & European Employment Service & Europejske Stużby Zatrudnienia \\
\hline ISP & $\begin{array}{l}\text { Institute of Political Studies of the } \\
\text { Polish Academy of Sciences }\end{array}$ & $\begin{array}{l}\text { Instytut Studiów Politycznych Polskiej Akademii } \\
\text { Nauk }\end{array}$ \\
\hline KIS & Social integration club & Klub Integracji Społecznej \\
\hline LF & Labour Fund & Fundusz Pracy \\
\hline MEB & Main Employment Board & Naczelna rada zatrudnienia \\
\hline MGiP & Ministry of Economy and Labour & Ministerstwo Gospodarki i Pracy \\
\hline MPiPS & Ministry of Labour and Social Policy & Ministerstwo Pracy i Polytiky Społecznej \\
\hline NAPE & National Action Plan on Employment & Krajowy Ptan Działań na Rzecz Zatrudnienia \\
\hline NGO & Non-government organisation & Organizacja pozarzqdowa \\
\hline $\mathrm{OHP}$ & Voluntary Work Corps & Ochotnicze Hufce Pracy \\
\hline OPS & Social assistance centre & Ośrodek pomocy społecznej \\
\hline PES & Public employment service & Publiczne slużby zatrudnienia \\
\hline PLN & Polish Zloty & Ztoty polski \\
\hline PUP & Poviat labour office & Powiatowy urzqd pracy \\
\hline VEB & Voivodeship employment board & Wojewódzka rada zatrudnienia \\
\hline WUP & Voivodeship labour office & Wojewódzki urząd pracy \\
\hline ZUS & Social Security Institution & Zakład Ubezpieczeń Społecznych \\
\hline
\end{tabular}


DELSA/ELSA/WD/SEM(2009)8

\section{MAIN FEATURES OF THE PES IN POLAND}

\section{Introduction}

1. This report documents the main features of the Public Employment Service (PES) in Poland. It focuses on institutional structures, staff and budgetary resources, statistics for PES operations and benefit eligibility criteria and their enforcement. These are all key elements for understanding national activation policies.

2. A first section describes the institutional structure of the PES and other active labour market programmes. A second section provides data about PES staff and workload, and estimates the level of public expenditure on PES functions. A third section describes unemployment insurance benefits, and a fourth section describes social assistance benefits.

\section{Institutional structure}

3. The restructuring of the economy that was launched in Poland in early 1990s brought about an unprecedented scale of layoffs and reduced job creation resulting in high unemployment, economic inactivity and poverty. The public employment service (PES), which had been virtually unnecessary in the socialist "full-employment" economy, ${ }^{1}$ became indispensable for assisting jobless people to navigate in the changing labour market. During the 1990s, the PES was a specialised state administration governed by the National Labour Office and supervised by the Minister responsible for labour issues. Labour offices (biura pracy) operated at two institutional levels, the provinces (voivodeship) and counties.

4. The reform of territorial administration undertaken in 1998 introduced important changes to the public administration. A majority of tasks in the area of employment and social, health and housing policies were decentralised to the local level (Wóycicka, 2005). These changes significantly affected the delivery of public employment services, too. From January 2000, labour offices were fully, in terms of assets and staff, transferred under the competence ${ }^{2}$ of self-governments. ${ }^{3}$

5. The territorial administration of Poland operates at three levels. There are 16 voivodeships where the state is represented by a voivode (province governor) appointed by the Prime Minister. The self-governing structures include the sejmik (voivodeship parliament) elected by the inhabitants and a marszatek (head of the voivodeship self-government) elected by the sejmik. Each voivodeship covers the territory of many poviats (counties). At present, there are 308 poviats and 65 cities with the status of a poviat. The poviat is governed by a directly elected poviat council (rada powiatu) and a starosta (head of poviat) elected by that council.

1. The public employment service has been in existence in Poland since 1918.

2. This text several times uses the word "competence" in the French sense, which refers to powers and responsibilities rather than capacity or ability.

3. This text several times refers to "self-governments", a generic term for governments which derive their authority from elections at regional and local level. 
6. A gmina is the lowest administration unit in Poland. Although the closest equivalent for the term would be a municipality in fact a gmina is a community of several municipalities or villages (wioska). At present, there are 2489 gminas of three types, i.e. urban, urban-rural, and rural. A gmina is governed by a mayor (called wójt in rural gminas and burmistrz in urban and urban-rural gminas) and a gmina council (rada gminy). The representatives of both institutions are directly elected by gmina inhabitants.

\section{A. Basic information on the institutional framework}

7. Since 2000, the public employment service (PES) in Poland has been delivered both by territorial self-governments through 16 voivodeship labour offices (WUP) and 340 poviat labour offices (PUP) as well as by state administration bodies, namely the Minister responsible for labour and social policies, 16 voivodes, and the Voluntary Work Corps (Ochotnicze Hufce Pracy, OHP). Each body is autonomous with no hierarchical relationship with any other.

8. The Minister is responsible for the regulation and coordination of the PES at all levels. He/she issues detailed standards of delivery of labour market services and determines instruments and methods to be used by PUP and WUP in the framework of active labour market programmes, for which he/she allocates resources from the Labour Fund. Thus, both the delivery standards and delivery instruments are set at a central level aiming at an overall coherence of the system.

9. In addition, the Minister represents PES at the international level and coordinates activities related to the free movement of workers. In the Ministry several organisational units are engaged in the agenda of employment promotion, namely the Labour Fund Department, Labour Market Department, Migration Department and the European Social Fund (ESF) Implementation Department.

10. The voivodes supervise PUP and WUP in terms of their adherence to the delivery standards issued by the Minister. They also ensure that the staff in labour offices meet the required qualification standards ${ }^{4}$ and that the tasks as defined in law are properly implemented at a local level.

11. The voivode's office also serves as an appeal institution for decisions taken by PUP and WUP. The fact that a state administration body decides about appeals against decisions taken by self-government institutions on issues falling within the framework of their own tasks is in conflict with the general legal principle that, for the self-government's own tasks, the appeals should be treated by the self-government appeal college (Samorzadowe Kolegium Odwolawcze). However, in this case there is special national legislation giving the function of an appeal institution to a state administration body (MPiPS, 2007a). ${ }^{5}$

12. The state's competences in the area of employment promotion have gradually been decentralised to a local level. While in 1998 the poviats delivered both their own competences and the competences devolved from the state, in 2004 all these tasks became the poviat's own tasks. The share of state budget subsidies to PUP and WUP for the tasks devolved by the state dropped from $90 \%$ in 2003 to $6.1 \%$ in 2004 (Table 1).

4. The qualifications required are set centrally and defined in the Act of 20 April 2004 on employment promotion and labour market institutions.

5. In 2007, the Warsaw Labour Office issued 127906 administrative decisions on which they received 1453 appeals. Of these, 418 were submitted to the Warsaw voivode. Of that number, 84 decisions of the Warsaw Labour Office were overturned by the voivode and in 17 cases the voivode stated that the decision taken by the Warsaw Labour Office was irrelevant. The majority of the appeals related to de-registration from the unemployment registry on grounds of refusal of suitable work and to cases when unemployment insurance benefit was not granted (WAW, 2007). 
DELSA/ELSA/WD/SEM(2009)8

Table 1. State budget transfers to poviat and voivodeship labour offices, 2000-2005

Percentages $^{a}$

\begin{tabular}{lrrrrrr}
\hline & $\mathbf{2 0 0 0}$ & $\mathbf{2 0 0 1}$ & $\mathbf{2 0 0 2}$ & $\mathbf{2 0 0 3}$ & $\mathbf{2 0 0 4}$ & $\mathbf{2 0 0 5}$ \\
\cline { 2 - 7 } PUP & 97.0 & 94.3 & 90.1 & 90.1 & 0.0 & $0.9^{b}$ \\
WUP & 0.0 & 100.7 & 93.5 & 89.4 & 28.6 & 41.8 \\
Total & $\mathbf{9 7 . 0}$ & $\mathbf{9 5 . 1}$ & $\mathbf{9 0 . 5}$ & $\mathbf{9 0 . 0}$ & $\mathbf{6 . 1}$ & $\mathbf{1 3 . 5}$ \\
\hline
\end{tabular}

a) Share of state budget subsidies, for the tasks devolved by the state, within total PUP and WUP expenditures.

b) The state subsidies to PUP in 2005 support capital expenditure only.

Source: MPiPS (2007a).

13. At the poviat level, labour offices belong to poviat self-administration and fall under the competence of a starosta. Yet unlike other poviat agendas, they have not become an integral part of the poviat office (starostwo poviatowe) but have continued to operate as separate institutions. The same applies to WUP, which first became part of the marszatek office in 2000 but since 2004 have operated separately. Labour offices are managed by directors appointed by starostas and marszateks on the basis of

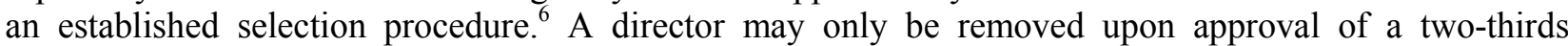
majority of members of the relevant Employment Board. ${ }^{7}$

14. Although starostas and marszateks formally have full powers in terms of labour market services, they normally delegate responsibility for delivery of the services to the directors of labour offices. Thus labour offices have, even after their decentralisation, preserved their internal independence. PUP and WUP directors act independently in terms of human resource management. They appoint their deputies and conclude employment relationships with all staff, even though officially the labour office staff are employed by the self-government and are subject to the legislation on self-government officers.

15. The WUP basically perform three main functions: $i$ ) they coordinate the design and implementation of policies related to the labour market and human resource development at a voivodeship level, ii) they allocate Labour Fund resources obtained from the central level to the PUP according to the priorities adopted by the sejmik, and iii) they are responsible for programming the use of the European Social Fund resources. WUP run centres for information and career guidance that supplement PUP activities with specialised services, such as collection and dissemination of vocational information and the operation of activation classes for the unemployed. ${ }^{8}$

16. The main mission of the PES - helping people to move from unemployment to work - is delivered by the PUP. They provide job-search assistance to the unemployed and jobseekers, ${ }^{9}$ assist employers in finding suitable employees, provide vocational counselling, implement various active labour market programmes (Box 1) and run job clubs (see Section 2 below). The PUP decide about entitlements to the unemployment insurance benefits and pay these benefits. ${ }^{10}$

6. Applicants for the positions of WUP or PUP directors shall have higher educational attainment, at least three years of work experience in PES or five years in another labour market institution or in an enterprise on a post related to the management of human resources (MPiPS, 2004a).

7. The Employment Board is a consultation body for labour market issues that operates at all levels of governance. For more details see the section on Decentralisation and governance.

8. Activation classes are classes/workshops organised for unemployed people and jobseekers aimed at their preparation for individual job search and employment (MPiPS, 2004a).

9. A jobseeker is a person not in employment who is seeking employment or other paid work, or an employed person declaring the intention and readiness to undertake other work or employment involving more working time, or additional employment or other paid work, who is registered in a PUP (MPiPS, 2004a).

10. Before 2004, PUP also paid pre-retirement benefits and allowances. 


\section{Box 1. Active labour market programmes in Poland}

The PES in Poland provides a standard range of active labour market programmes including training, vocational preparation at a work place or subsidised employment. All programmes are financed from the Labour Fund resources.

The programme of intervention works (prace interwencyjne) provides subsidised jobs to unemployed people based on an agreement between a poviat starosta and an employer. The programme is targeted at centrally-defined categories of unemployed who are considered to face a difficult situation on the labour market, namely unemployed who are below 25 years of age, long-term unemployed, women who have not returned to work after maternity leave, unemployed over 50 years of age, unemployed with no professional qualifications, no occupational experience or lower than secondary educational attainment, unemployed lone parents maintaining a child below 18 years of age, unemployed ex-offenders who have not returned to work, and disabled unemployed.

Poviats reimburse to employers the wage costs of people hired under the programme. The duration and the amount reimbursed varies by target group. The level of support ranges from reimbursement of the amount of the unemployment insurance (UI) benefit for six months (as the minimum level of support for all categories) to the reimbursement of the amount of minimum wage every second month for four years (for unemployed above 50 years of age).

In addition to the reimbursement of wage costs, employers may receive financial assistance for the purpose of equipping the work place concerned. In return, employers are obliged to keep these work places for 2 years (in case of small and medium enterprises) or 3 years (large enterprises). Unemployed people hired under the programme must be kept by the employer for a minimum period of 12 months.

Public works (prace publiczne) provide work for a maximum 12 months in jobs organised by gminas and non-governmental organisations that operate in environmental protection, culture, education, health care, unemployment or social assistance, and by water companies and their associations. They are financed or co-financed by the self-governments, state budget, earmarked funds, non-governmental organisations, and water companies and their associations. Public works are targeted at the same categories as intervention works with the exception of the young unemployed below 25 years of age. Organisers of public works are reimbursed the wage costs of the hired unemployed people, up to a maximum of $50 \%$ of the average wage in the economy, for up to 12 months.

Young unemployed may be referred to work experience (staż), which is often their first work experience, without concluding an employment contract with the employer. Through this programme, the unemployed below 25 years of age, or below 27 years of age when higher education graduates are concerned but within 12 months from graduation, acquire practical skills by performing tasks at a real work place under the supervision of a tutor. The duration of work experience can be from a minimum of 3 to a maximum of 12 months.

Through vocational preparation at a work place (przygotowanie zawodowe w miejscu pracy) the unemployed acquire new professional qualifications or skills by performing practical tasks at a real work place according to a determined programme, without concluding an employment contract with the employer. Its duration is from 3 to 6 months. This programme is targeted at the same categories as public works. Under both programmes (work experience and vocational preparation at a work place), the unemployed receive a "scholarship" of $140 \%$ of the UI benefit amount.

Unemployed people may be referred to training financed from the Labour Fund if they have no professional qualifications, or, due to the unavailability of suitable work, need to complete or change their qualifications, are no more capable of performing up-to-date work or have no skills in active job search. People participating in training receive a training allowance (a supplementary payment, dodatek szkoleniowy) of $20 \%$ of the UI benefit amount. Young unemployed below 25 years of age receive a scholarship of $40 \%$ of the basic UI benefit amount. People undertaking training outside their place of residence may be reimbursed incurred travel costs.

The programme of socially useful works is targeted at registered unemployed people with no entitlement to the $\mathrm{UI}$ benefit who are at the same time clients of gmina social assistance centres. The programme has a triple mission:

- $\quad$ Provide the unemployed people with at least minimum income;

- Support development at a community level; and

- $\quad$ Contribute to the prevention of illegal work. 


\section{Box 1. Active labour market programmes in Poland (Cont.)}

People are referred to the programme by a PUP upon the proposal of the relevant gmina office. They perform work in their place of residence for a maximum of 10 hours per week. For each hour actually worked, the participants receive a minimum allowance of PLN 6. Participation in the programme is not limited in time and people may undertake this kind of work even for more than one year. During participation their health insurance is covered by a PUP. The gmina's expenditures, up to the amount of $60 \%$ of the minimum allowances, are refunded by a poviat starosta from Labour Fund resources.

Recipients of UI benefits who accept part-time work offered by a PUP involving remuneration below minimum wage may be granted an activation allowance. The activation allowance is granted over the period of UI eligibility at a level not exceeding $50 \%$ of the UI benefit. The activation allowance may also be granted when UI beneficiaries take up work based on individual job search. In this case, the activation allowance is granted for up to half the period of UI eligibility at the level of $50 \%$ of the UI benefit.

Young people below 25 years of age with no professional qualifications and fulfilling the family income criterion (according to the legislation on social assistance) who within 6 months from registration start further education are entitled to a scholarship of $50 \%$ of the basic level of the UI benefit for 12 months. The supported period may be extended by a poviat starosta.

Registered unemployed people may be given a lump-sum grant for launching self-employment activities of up to $500 \%$ of the average wage in the economy.

Table 2 shows estimated numbers of people returning to unemployment after participation in active labour market programmes. It is important to note that in Poland, participation in active labour market programmes leads to exit from the unemployment register. In a majority of cases, public works and socially useful works did not lead to a transition to the open labour market. Their mission rather consists in maintaining working habits of the hard-to-employ. Similarly, work experience and vocational preparation at a workplace did not lead to the employment of participants. By contrast, we estimate that around $66 \%$ of people undertaking intervention works were retained by employers for more than the subsidised period of 12 months.

Source: MPiPS (2004a); and www.psz.praca.gov.pl.

17. The picture of public employment service in Poland would be incomplete without mentioning the Voluntary Work Corps (OHP). It targets young people at risk of social exclusion and undertakes actions aimed at improving their educational attainment and/or qualifications, and provides job-search assistance and vocational counselling. In addition, it reimburses part of the labour costs incurred by the employers who hire its clients. OHP activities are complemented by affiliated job clubs, youth job offices, mobile centres of employment information, and training centres. The OHP complements the activities of other PES institutions by reaching out to groups that, due to their age, cannot benefit from standard labour market services.

18. Unlike labour offices, OHP have not been decentralised to self-governments. They are state budget entities established within the structures of voivodeship offices but directly supervised by the Minister. As they are not legal entities, they do not own assets and are not financially independent. Their activities are financed from the state budget and the Labour Fund, although under certain conditions they may make a profit and subsequently use it for their activities. Considering the character of the OHP mission, it is interesting that they were not affected by the advanced process of PES decentralisation in Poland. "Given the scale and the territorial character of their activities such a system is perceived as excessively centralised" (MPiPS, 2007a). 


\begin{tabular}{|c|c|c|c|c|c|c|}
\hline \multicolumn{7}{|c|}{ Units } \\
\hline & $\begin{array}{l}\text { Intervention } \\
\text { works }\end{array}$ & Public works & $\begin{array}{c}\text { Work } \\
\text { experience }\end{array}$ & $\begin{array}{c}\text { Vocational } \\
\text { preparation at a } \\
\text { work place }\end{array}$ & Training & $\begin{array}{l}\text { Socially useful } \\
\text { works }\end{array}$ \\
\hline \multicolumn{7}{|c|}{ Total number of participants during the year } \\
\hline & 69050 & 32655 & 169100 & 58300 & 147139 & 70200 \\
\hline \multicolumn{7}{|c|}{ Persons returning to unemployment after completing individual programmes in individual months } \\
\hline January & 2546 & 8104 & 16882 & 6455 & 3885 & 930 \\
\hline February & 982 & 1124 & 14738 & 5502 & 5194 & 960 \\
\hline March & 1409 & 928 & 17539 & 6864 & 8574 & 1482 \\
\hline April & 1423 & 719 & 13603 & 5840 & 10651 & 2894 \\
\hline May & 1061 & 760 & 9686 & 2892 & 10294 & 4171 \\
\hline June & 1022 & 1103 & 10118 & 2568 & 14036 & 5166 \\
\hline July & 2189 & 1683 & 11481 & 3328 & 15606 & 5435 \\
\hline August & 1609 & 1056 & 12210 & 4225 & 11409 & 4367 \\
\hline September & 2128 & 1469 & 16669 & 6186 & 13308 & 5339 \\
\hline October & 3076 & 3082 & 15373 & 5646 & 14669 & 7165 \\
\hline November & 2839 & 3113 & 12214 & 5910 & 17762 & 7419 \\
\hline December & 2528 & 4819 & 19013 & 6368 & 20281 & 11699 \\
\hline $\begin{array}{l}\text { Yearly total } \\
\text { Percentages of all }\end{array}$ & 22812 & 27960 & 169526 & 61784 & 145669 & 57027 \\
\hline participants $^{a}$ & 33.0 & 85.6 & 100.3 & 106.0 & 99.0 & 81.2 \\
\hline
\end{tabular}

a) Values exceeding $100 \%$ appear for some programmes. Total number of participants refers to starts in 2006 (i.e. statistics refer to the flow of new entrants to the programme). Persons returning to unemployment includes people who started the programme in 2005. Both statistics may include two or more spells in the programme for the same person.

Source: www.psz.praca.gov.pl; and author's calculations.

\section{B. Decentralisation and governance}

19. The delivery of public employment services in Poland is highly decentralised. The main PES providers - labour offices - fall under the competence of territorial self-governments. The state has retained responsibilities in terms of coordination and supervision of service delivery and significant powers in terms of policy-making.

20. This shift of employment-service competences from the state to a local level has largely been perceived as a positive step. Previously, it was difficult to determine the share of financing between the devolved and own competences (see Table 1 above), which created a rather complex situation. Moreover since the services provided by PUP have always been closely related to the local dimension, there existed no rationale for keeping them under the competence of the central administration (MPiPS, 2007a). Decentralisation was implemented in several stages, and in 2000 all tasks delivered by PUP came under their own competences.

21. Nevertheless, some labour office directors "were concerned about the swing from a centralised to a decentralised system. Some felt that this had weakened the national dimension of the system, that local offices were working independently from each other, ..., and that as a consequence delivery standards differed between one office and another, and lines of responsibility were not clearly drawn" (Sultana and Watts, 2005). 
22. There were also concerns that the decentralisation had deepened the differences in service provision not only between offices but also across voivodeships. Significant regional variation in the level of spending from the Labour Fund may be a sign of efficiency gaps (MPiPS, 2007a). These might have resulted from differences in the quality and quantity of staff (since staffing is determined by the self-governments) as well as limited coordination among labour offices (RWI, 2005). The problem is that labour offices have no umbrella organisation that would initiate and coordinate mutual exchange of best practices and other information flows (MPiPS, 2007a).

23. Recently WUP and PUP created informal structures for discussing and coordinating common issues - the Convention of WUP directors and the Forum of PUP directors. Interestingly, these bodies do not voice their opinions through the Main Employment Board, the main advisory body of the Minister. Rather, they try to directly approach the Minister or voice their demands through the members of the national parliament.

\section{Designing policies and programmes}

24. The priorities and directions of employment policy are defined at the central level. They are presented in the National Reform Programme and further elaborated in the National Action Plan on Employment (NAPE) for individual years. The NAPE is drafted by an inter-ministerial working group and presented for comments to the Main Employment Board and other social partners. The WUP are also consulted. The final version of the NAPE is adopted by the Council of Ministers and presented to the Sejm (lower chamber of the national parliament). ${ }^{11}$

25. The NAPE provides the framework for the development of voivodeship action plans on employment, which are part of regional development strategies. Voivodeship action plans are developed by the marszatek's office and define priorities in terms of types of interventions, projects and target groups. Poviat self-governments and social partners operating at a voivodeship level should be consulted in the process of plan development. ${ }^{12}$

26. Research shows that the implementation of the National Reform Programme at each lower territorial level focuses progressively more on combating unemployment, instead of concentrating on actions to support employment growth. But this is not inconsistent with the legislation drafted at the central level, where the majority of tasks assigned to labour offices relate to reducing unemployment and mitigating its effects. The law defines only few services aimed at assisting in the process of restructuring and adaptation, such as supporting employee training. In general, labour offices do not provide training for groups who are not yet unemployed but, due to obsolete qualifications, are threatened by layoffs. In fact, this group cannot count on the assistance of any public institution in Poland (MPiPS, 2007a).

27. The Act on Employment Promotion and Labour Market Institutions adopted in 2004 increased the role of territorial self-governments in developing employment-related programmes according to local needs. Previously, decentralisation in Poland was limited to the delivery of public employment service and did not concern other areas of policy-making. Today, in addition to centrally-designed employment policies and programmes, the self-governments may develop and implement their own programmes, for which they may receive funding from the Minister's reserve in the Labour Fund. However, the local

11. Yearly NAPE implementation reports are also presented to the Sejm.

12. According to MPiPS (2007a), 90\% of the surveyed PUP confirmed they were consulted by the WUP and their inputs were used in developing the voivodeship action plan. More than $70 \%$ of the surveyed PUP stated that the regional action plan is an effective instrument for coordinating the activities within a voivodeship. 
programmes should not much deviate from centrally-designed policies, and must include at least one of the priority actions defined in the NAPE and further elaborated in voivodeship action plans on employment.

28. In terms of procedures, the Minister issues a call for proposals and gives voivodeships two months for submitting one or more programme proposals. Financial support from the Minister's reserve is approved for programmes with particular importance for the voivodeship labour market, provided that co-financing by the partners and the voivodeship self-government has been ensured. The Ministry then determines how the approved amount shall be allocated to individual poviats.

29. Many poviats develop programmes for employment promotion and activation of the local labour market that form part of the poviat strategies for responding to social problems. Despite their relative independence in organising the direct delivery of employment services, in terms of designing broader local policies and programmes the PUP remain dependent on the poviat office (starostwo) and on the scale of financing approved by the poviat council. Also, the PUP are always bound by the tasks defined in law.

\section{Setting eligibility and targeting criteria}

30. PES tasks and instruments are determined at the central level and are elaborately defined in legislation. The 2004 Act defines in detail all types of interventions as well as target groups. The unemployed have a legal entitlement to labour market services, and to receiving referrals to jobs and/or labour market programmes, however for these it is finally up to the individual PUP to determine detailed eligibility criteria according to local priorities and personal characteristics of the client.

31. The targeting criteria designed at the central level do not always match with the situation on local labour markets and before the adoption of new legislation in February 2009 the poviats could not extend participation in active labour market programmes to other groups not defined in the legislation. Even the ESF programmes were only accessible to the centrally defined target groups. Thus, the types of interventions implemented by labour offices across the country are almost identical ${ }^{13}$ and do not respond to local specificities. Even though there are poviats that try to reach out to specific groups, ${ }^{14}$ the targeting is seldom preceded by solid analyses.

32. Poor understanding of the overall labour market situation is a widespread problem of the Polish self-government structures. This is due to the weakness of the information bases that the local governments have at their disposal, poor analytical competences of the PES staff and lack of resources for outsourcing labour market research (MPiPS, 2007a).

33. Voivodeships and poviats are formally consulted when drafting and amending legislation but they do not have a significant role in policy-making. "Rather they fulfil their legally defined tasks of providing and managing employment services defined at the central level" (European Commission, 2005). The view that labour offices (can) hardly do more than mechanically implement the instruments defined in law has frequently been expressed in reports, as well as by staff interviewed in labour offices.

13. In one PUP the interviewed staff mentioned that although the programmes are in principle identical, they may be delivered with some nuances, e.g. some PUP combine self-employment support with training while others do not; or the way in which the unemployed and the jobseekers are informed may also vary; and some PUP organise job fairs while others only produce leaflets.

14. European Structural Fund resources allow the implementation of non-standard programmes, additional to those defined in the legislation. 


\section{Negotiating annual performance objectives}

34. Performance objectives are determined at a voivodeship level and approved by the sejmik. They reflect voivodeship strategies developed in co-operation with main voivodeship stakeholders. However, the programmes must also be approved by the Minister who should also receive reports about their implementation. Should the Minister consider the performance objectives set at the voivodeship level to be insufficiently ambitious, marszateks may be invited to raise them.

35. Performance criteria often create a conflict of priorities. PUP performance is evaluated according to the rate of entry to work of programme participants over a period of time. This creates adverse effects with respect to local policies, as it motivates to pushing the unemployed out to work as soon as possible, with little consideration about the job's quality. No follow-up monitoring of the client's employment track is undertaken (MPiPS, 2007a).

\section{Developing and maintaining relationships with other labour market actors}

36. The main forum for co-operation and consulting labour market policies with other stakeholders are so-called employment boards operating at all levels of governance, i.e. the national, province and poviat levels.

37. The Main Employment Board (MEB) is the Minister's advisory and consulting body. Its mission includes initiating actions focused at employment growth and human resource development on the national level, evaluating projects implemented under the NAPE and voivodeship action plans, activities financed from the Labour Fund, and evaluating the management of the Labour Fund. It also provides opinions on drafts of employment legislation. MEB members are appointed by the Minister from among the representatives of trade unions and employers' organisations that are considered representative according to law, ${ }^{15}$ national associations of territorial self-governments, voivodeship employment boards, non-governmental organisations (NGOs), and academic circles. ${ }^{16}$

38. Voivodeship employment boards (VEB) are consulted about criteria for determining the Labour Fund allocations to individual poviats and on the voivodeship's priorities in terms of schooling and vocational training. ${ }^{17}$ Each VEB delegates one representative to the MEB.

39. In spite of an apparently well-established system of employment boards and their recognition ${ }^{18}$ by the central and local governments, their real impact on the policy making at decentralised levels is

15. Act of 6 July 2001 on the Trilateral Committee for Social and Economic Issues and provincial committees for social dialogue.

16. Representatives from the academic sector are delegated to the MEB by the Labour and Social Policy Committee of the Polish Academy of Sciences (MPiPS, 2004a).

17. VEB members are appointed by voivodeship marszateks and include delegates of each representative trade union and employers' organisation operating at a voivodeship level, social and trade unions of farmers, poviat employment boards, NGOs operating in the area of the labour market, and the academic sector. Other non-member organisations may be invited to delegate a representative to a concrete board session when issues of employment promotion and mitigation of the impacts of unemployment are to be discussed in detail. Such organisations, including e.g. the associations of unemployed people, are invited to present their opinions on the discussed matter. These processes are set out in MPiPS (2004c), but there are poviats where the co-operation with social partners is traditionally poor or even non-existent. For instance, in the Warsaw Employment Board no social partners are represented.

18. Training of the employment board members may be financed from the Labour Fund resources. 
disputed. According to PUP and WUP staff, the actual impact of employment boards on the setting of objectives and the selection of activities to be delivered by labour offices is very low (MPiPS, 2007a).

40. Similar statements were cited with respect to other local actors such as NGOs, private employment agencies, and employers' organisations although one would expect that the decentralisation would have initiated closer co-operation at a local level. Being part of the local self-government, the PUP should undertake the role of a local animator and coordinator of employment-related initiatives (MPiPS, 2007a).

41. Although PUP and WUP directors declare the importance of co-operating with other stakeholders, the effect of such co-operation is in fact very limited. The PUP officers often believe that labour offices are self-sufficient, maybe also because they doubt professional competences of staff in other institutions, especially the NGOs. Conversely, NGOs, too, rarely take the initiative in approaching labour offices and, like the PUP, they are convinced that they know much better how to proceed. The PUP also claim that the proper delivery of tasks as required in law excludes the possibility of co-operating with other institutions (MPiPS, 2007a). Other institutions with whom PUP, with different levels of intensity, co-operate include education institutions, psychological-pedagogic centres, school career centres, academic career bureaus, and entrepreneurship support centres.

42. The starostwo (poviat self-government office) should be PUP's closest partner. But here too, the picture of real co-operation is not convincing. More than a quarter of PUP surveyed by MPiPS (2007a) declared no co-operation with organisational units of the starostwo office. What is most evident is a lame collaboration with social assistance centres (ośrodek pomocy społecznej, OPS) operating at gmina level. The OPS target people and families in difficult social situations that most often have been caused by the unemployment of one or more family members. Such situations call for joint OPS and PUP interventions. But the co-operation, although declared by all surveyed labour offices, is in fact limited to exchanging information about their programmes. Less than $50 \%$ of surveyed PUP undertook with OPS joint initiatives $^{19}$ or projects that would deliver any form of activation of unemployed recipients of social-safety-net benefits (MPiPS, 2007a; see also Section 4 below).

43. The above description of PUP relationships with other local actors suggests that the position of labour offices on the regional and local labour markets is rather isolated. Their role as local coordinator of labour market interventions may thus be quite limited.

44. On a vertical level, co-operation between the PUP and the WUP is viewed as good although its scope and extent differs between individual voivodeships. The most noticeable sign of collaboration is the active involvement of the PUP in strategic planning at a voivodeship level. The majority of PUP actually consider the regional action plan on employment to be "a real instrument of task coordination at a voivodeship level" (MPiPS, 2007a). Even though there is no form of hierarchic subordination between PUP and WUP, the scope and usefulness of information flows is quite good. The organisation of joint training for WUP and PUP staff represents another form of mutual co-operation.

45. In the opposite direction, however, the PUP lack appropriate partners at a gmina level. Slightly over $60 \%$ of gminas operate so-called gmina information centres which deal with labour market issues, but less than half of them undertake joint actions with the PUP (MPiPS, 2007a).

19. Social integration centres and social integration clubs, described in Section 4. 


\section{Outsourcing}

46. The 2004 Act on Employment Promotion and Labour Market Institutions introduced a possibility of outsourcing some PES tasks, namely placement services, EURES services, the provision of vocational counselling and information, assistance with active job search and training of the unemployed or jobseekers (MPiPS, 2007c).

47. Decisions on the scale of outsourcing are taken by the starosta or marszatek but they must always fit within the budget of each labour office. Either services are purchased directly or (in the case of larger contracts) an invitation to tender is issued and an external provider is selected in an open competition. The contracts are concluded for a maximum of three years. Starostas may also subcontract other types of services such as making analyses of the local labour market, collection and dissemination of vocational information, etc.

48. In practice, the main PES functions are contracted out on a very limited scale. Outsourced placement services or vocational counselling may not be financed from the Labour Fund allocations and PUP would have to use their locally-financed budget allocations, which are limited. As, according to interviewed PUP staff, outsourcing to external providers is much more expensive than delivering the services in-house, many PUP actually cannot afford it and use the locally-financed budget to support inhouse provision.

49. Thus, PUP are often in a situation when they have surplus financial resources from the Labour Fund but cannot spend them according to their needs. The addition of placement and vocational guidance to the list of services that can be financed from the Labour Fund resources might resolve the problem and stimulate outsourcing on a more significant scale. Subject to well-designed criteria for contracting out, this might at the same time contribute to a more efficient delivery of services.

\section{PES staff and workload indicators}

\section{A. PES staff}

50. The 2004 Act on Employment Promotion and Labour Market Institutions defines six main categories of PES staff, namely placement officers, vocational counsellors, vocational development specialists, programme specialists, job club leaders, EURES counsellors and EURES assistants. ${ }^{20}$ The functions of placement officers and vocational counsellors are sub-classified according to the level of acquired qualifications into trainee specialists, (regular) specialists, specialists $1^{\text {st }}$ grade and specialists $2^{\text {nd }}$ grade. Professional licenses authorising the people to perform a function of a certain grade are issued by a voivode according to criteria defined in law. ${ }^{21}$

51. Staffing is determined by the respective levels of governance (voivodeship or poviat self-governments) but must follow the centrally established systemisation of staff categories. ${ }^{22}$ Table 3 shows the development of total staffing between 2000 and 2006. From 2000 to 2002 the staffing had declined due to reduced posts in PUP. By contrast, from 2003 onwards the number of employees both in PUP and WUP has increased. From 2000 there is a clear downward trend in the PUP share in the total

20. In spite of the fact that the PUP have competences in terms of unemployment insurance benefits, they have no specific staff devoted to this agenda.

21. The general criteria are defined in MPiPS (2004a) and are further elaborated in a specific regulation issued by the Minister.

22. Although in 2007 the Minister defined minimum staffing for six categories of PES staff (see details in a note below). 
number of staff in labour offices. This trend is surprising as the main PES tasks are almost exclusively delivered at a poviat level, by PUP. It may partly be explained in terms of the increasing number of specialists for the ESF programmes and other EU agendas employed by WUP.

Table 3. Staffing in labour offices, $2000-2006^{a}$

Units and percentages

\begin{tabular}{|c|c|c|c|c|c|c|c|c|c|c|c|c|c|c|}
\hline \multirow[b]{2}{*}{ WUP } & \multicolumn{2}{|c|}{2000} & \multicolumn{2}{|c|}{2001} & \multicolumn{2}{|c|}{2002} & \multicolumn{2}{|c|}{2003} & \multicolumn{2}{|c|}{2004} & \multicolumn{2}{|c|}{2005} & \multicolumn{2}{|c|}{2006} \\
\hline & 1101 & 6.4 & 1139 & 6.9 & 1127 & 7.1 & 1450 & 8.2 & 1927 & 10.4 & 2108 & 10.7 & 2325 & 11.7 \\
\hline PUP & 16061 & 93.6 & 15347 & 93.1 & 14747 & 92.9 & 16185 & 91.8 & 16648 & 89.6 & 17542 & 89.3 & 17608 & 88.3 \\
\hline Total & 17162 & 100.0 & 16486 & 100.0 & 15874 & 100.0 & 17635 & 100.0 & 18575 & 100.0 & 19650 & 100.0 & 19933 & 100.0 \\
\hline
\end{tabular}

a) At the end of the year.

Source: MPiPs (2007d).

52. At the end of 2006 WUP and PUP employed 19933 staff (including managers) of whom $754(3.8 \%)$ were employed on a part-time basis. Table 4 presents full-time equivalents of staff in WUP and PUP in 2005 and 2006, separately listing the front-line placement and related staff categories. ${ }^{23}$

53. In 2006 the front-line placement and related staff represented only $20.1 \%$ of WUP and PUP total staff. These front-line staff together with managers represented $32.3 \%$ of total staff, so that almost $70 \%$ of staff in labour offices delivered administrative functions that according to the government strategies (e.g. National Action Plan on Employment) do not represent the PES main mission. When looking separately at PUP, where the main PES functions should be delivered with highest intensity, these staff devoted to substantive front-line contacts with clients only represented $20.6 \%$ of all PUP employees - or about $18.6 \%$ if programme specialists are not included. This is well below shares calculated in a similar way for Slovak Republic (29\%) and the Czech Republic (23\%) (Kalužná, 2008a, and 2008b). ${ }^{24}$

54. Even though the proportion of the back-office staff is remarkable, the front-office workers, too, are burdened by bureaucratic work. According to a survey among the PUP staff (MPiPS, 2007a), front-office workers devote more than $44 \%$ of their working time to administrative activities not directly related to the work with the unemployed. Indeed, placement officers decide about entitlement to unemployment insurance benefits, which are then processed by the financial management staff.

55. According to both the legislation and strategic documents, the main mission of labour offices in Poland consists in an effective mediation of jobs and candidates for work. With an improving situation on the labour market and increasing demand for suitable workers, employers increasingly need high-quality job-broking services. Hence, well-functioning placement services delivered on an intensive basis should be at the heart of PUP activities.

23. Note that the category of "front-line placement and related staff" as presented in Table 4 includes "programme specialists", who work on programme organisation, contracting, budget and finance and evaluation, and keep records of jobseeker participation. Their main contacts are often with employers implementing the programmes rather than with jobseekers.

24. Note that labour offices administer state social benefits in the Czech Republic and both social assistance benefits and state social benefits in the Slovak Republic. In estimates for placement and related services alone their front-line staff shares would be much higher. The PES organisations typically report to WAPES (the World Association of PES) that about three-quarters of their staff are "in contact with jobseekers" (www.wapes.org/files/xls/2007-012-EN.xls): those figures in principle include non-professional staff in the numerator and exclude "unemployment or social insurance" staff from the denominator. 
Table 4. Structure of staff in labour offices, 2005 and $2006^{a, b}$

\begin{tabular}{|c|c|c|c|c|}
\hline \multicolumn{5}{|c|}{ Units and percentages ${ }^{c}$} \\
\hline Function & \multicolumn{2}{|c|}{2005} & \multicolumn{2}{|c|}{2006} \\
\hline $\begin{array}{l}\text { WUP total } \\
\text { Of which: }\end{array}$ & 2108 & 100.0 & 2325 & 100.0 \\
\hline Managers & 337 & 16.0 & 331 & 14.2 \\
\hline Placement officers & 44 & 2.1 & 44 & 1.9 \\
\hline Vocational counsellors & 181 & 8.6 & 178 & 7.7 \\
\hline Vocational development specialists & 1 & 0.0 & 1 & 0.0 \\
\hline Programme specialists & 195 & 9.3 & 311 & 13.4 \\
\hline Job-club leaders & 0 & - & 0 & - \\
\hline EURES advisers $^{d}$ & 28 & 1.3 & 24 & 1.0 \\
\hline EURES assistants $^{d}$ & & & 8 & 0.3 \\
\hline Main functions total without managers & 449 & 21.3 & 566 & 24.3 \\
\hline $\begin{array}{l}\text { PUP total } \\
\text { Of which: }\end{array}$ & 17542 & 100.0 & 17608 & 100.0 \\
\hline Managers & 2064 & 11.8 & 2110 & 12.0 \\
\hline Placement officers & 1579 & 9.0 & 2041 & 11.6 \\
\hline EURES assistants ${ }^{e}$ & 74 & 0.4 & 148 & 0.8 \\
\hline Vocational counsellors & 601 & 3.4 & 694 & 3.9 \\
\hline Vocational development specialists & 249 & 1.4 & 253 & 1.4 \\
\hline Programme specialists & 261 & 1.5 & 352 & 2.0 \\
\hline Job-club leaders & 102 & 0.6 & 132 & 0.7 \\
\hline Main functions total without managers & 2866 & 16.3 & 3620 & 20.6 \\
\hline $\begin{array}{l}\text { Total staff in WUP and PUP } \\
\text { Of which: }\end{array}$ & 19650 & 100.0 & 19933 & 100.0 \\
\hline Managers & 2401 & 12.2 & 2441 & 12.2 \\
\hline Placement officers & 1697 & 8.6 & 2085 & 10.5 \\
\hline Vocational counsellors & 782 & 4.0 & 872 & 4.4 \\
\hline Vocational development specialists & 250 & 1.3 & 254 & 1.3 \\
\hline Programme specialists & 456 & 2.3 & 663 & 3.3 \\
\hline Job-club leaders & 102 & 0.5 & 132 & 0.7 \\
\hline Main functions total without managers & 3287 & 16.7 & 4006 & 20.1 \\
\hline
\end{tabular}

- Not applicable.

a) Totals include staff in the intervention works programme, whose salaries will be reported as partly spending of that programme and partly within the budget allocations of the PUP and WUP.

b) Figures for individual categories of staff (including those for managers) shown here relate only to the PUP and WUP units for registration, placement and counselling, labour market, services for the disabled, and European programmes. The figures for individual categories do not include administrative staff in these units, and a category breakdown of staff in other types of unit (see paragraph 60 in the main text) is not available at national level.

c) Second and fourth columns in italics.

d) For 2005, EURES assistants are included in the line above.

e) MPiPS (2007c) stated a single figure for 2005: 1653 placement officers including 74 local EURES assistants; for clarity the number of EURES assistants is shown in a separate line for both documented years.

Source: MPiPS (2007c); and author's calculations.

56. This mission, however, can hardly be achieved with the current numbers of staff devoted to placement services. Although the number of PUP placement officers as well as their share in the total number of PUP staff has been increasing since 2002 (Table 5), it is still too low with respect to the number of PUP clients. In 2006 there were on average 1132 registered unemployed for one placement officer (Table 6). ${ }^{25}$ Including other

25. In the Warsaw Labour Office, for instance, the average monthly inflow of new registrations in 2007 was 3480 . On average the front-line staff spent 60 minutes with one registered unemployed or jobseeker while the waiting time at the beginning of the month averaged 180 minutes due to high numbers of people registering (WAW, 2007). 
jobseekers, who are also entitled to PUP job-broking services, the average placement officer's workload amounted to 1159 clients. $^{26,}{ }^{27}$ Although the stock of registered unemployed has fallen since 2000, the annual inflow has changed little while the number of notified job offers has increased quite sharply (see Table 16 below).

Table 5. $\quad$ Placement officers, 2000-2006

Units and percentages ${ }^{a}$

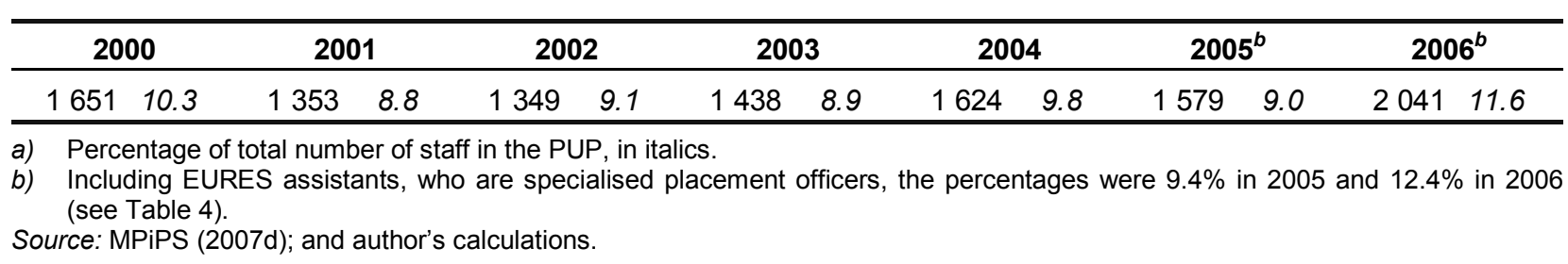

Table 6. Client/staff ratio for placement officers, ${ }^{a} 2000$ and 2006 Units and ratios ${ }^{b}$

\begin{tabular}{lrr}
\hline & $\mathbf{2 0 0 0}$ & $\mathbf{2 0 0 6}$ \\
\cline { 2 - 3 } Placement officers & 1651 & 2041 \\
Registered unemployed & 2702576 & 2309410 \\
Registered jobseekers &.. & 56768 \\
Unemployed per placement officer & 1637 & 1132 \\
Total clients per placement officer &.. & 1159 \\
\hline
\end{tabular}

\footnotetext{
. Data not available.

a) Data refer to PUP staff and the number of registered unemployed at the end of the year. Note that the 2006 total for placement officers could also, including EURES assistants, be cited as 2189 (see Tables 4 and 5) implying slightly lower ratios of unemployed per placement officer.

b) Two bottom lines in italics.

Source: MPiPS (2007a); and author's calculations.
}

57. Consequently, public job broking has quite a low reputation in Poland and its market share is rather poor. According to some studies (e.g. MPiPS, 2006c) this distrust in PES placement services "for sure results from their inefficiency, and/or from the employers' conviction about their low efficacy as they fail in mediating the best possible workers". Research shows that in spite of the legal obligation to notify all vacancies, only about half of all enterprises contact PUP when they want to recruit new employees. Less than $40 \%$ of them actually hired a worker thanks to the assistance from a PUP (MPiPS, 2007a). Jobseekers, too, report distrust in the possibility of finding a work via PUP (for more details see the subsection Registered vacancies and placements below).

58. It is important to note however that the importance of any institutional form of job broking in Poland is rather feeble. This "makes the labour market less transparent and raises the costs of matching both for jobseekers as well as employers looking for workers. Moreover, inadequate use of official forms of job broking isolates from work the people with lower social capital even though, by virtue of their skills, they could otherwise become valuable workers." (MPiPS, 2006c).

26. The Polish client/staff ratios are very high in comparison with the neighbouring countries. In 2006 there was 1 front-line staff for 116 registered unemployed in the Slovak Republic, and 1 for every 270 registered unemployed in the Czech Republic (see the reports on these countries by the same author).

27. In 2007 the Minister issued a regulation determining minimum required staffing for the six main categories of PES staff according to an algorithm. The mandatory number of placement officers, for example, depends on the total number of unemployed people registered in the PUP over the preceding year, the total number of de-registered unemployed and the total number of job offers notified by the PUP over the same period (MPiPS, 2007i). 
59. Insufficient staffing is reported with respect to the delivery of vocational counselling, too. Although this type of service has experienced significant development in absolute numbers of staff (Table 7), the coverage of demand is still insufficient. Based on the registered unemployed and registered jobseekers total in 2006 (2 366 178), there was one vocational counsellor for every 3409 PUP clients (Table 8). Individual vocational counselling was provided to 316300 people (456 for 1 counsellor) (MPiPS, 2007m).

Table 7. Vocational counsellors, 2000-2006

Units and percentages ${ }^{a}$

\begin{tabular}{|c|c|c|c|c|c|c|c|c|c|c|c|c|c|}
\hline \multicolumn{2}{|c|}{2000} & \multicolumn{2}{|c|}{2001} & \multicolumn{2}{|c|}{2002} & \multicolumn{2}{|c|}{2003} & \multicolumn{2}{|c|}{2004} & \multicolumn{2}{|c|}{2005} & \multicolumn{2}{|c|}{2006} \\
\hline 477 & 3.0 & 453 & 3.0 & 482 & 3.3 & 557 & 3.4 & 627 & 3.8 & 601 & 3.4 & 694 & 3.9 \\
\hline
\end{tabular}

a) Percentage of total number of staff in the PUP, in italics.

Source: MPiPS (2007d); and author's calculations.

Table 8. Client/staff ratio for vocational counsellors, ${ }^{a} 2000$ and 2006 Units and percentages ${ }^{b}$

\begin{tabular}{lrr}
\hline & $\mathbf{2 0 0 0}$ & $\mathbf{2 0 0 6}$ \\
\cline { 2 - 3 } Vocational counsellors & 477 & 694 \\
Registered unemployed & 2702576 & 2309410 \\
Registered jobseekers &.. & 56768 \\
Unemployed per counsellor & 5666 & 3328 \\
Total clients per counsellor &.. & 3409 \\
\hline
\end{tabular}

\footnotetext{
.. Data not available.

a) Data refer to PUP.

b) Two bottom lines in italics.

Source: MPiPS (2007a, and 2007c); and author's calculations.
}

60. The specific staff categories listed in Table 4 represent only $32 \%$ of total employment in the PUP and WUP. They do not include either the administrative staff in the placement and related units, or any of the staff in other units. In a typical PUP organisational structure, the other units would include a legal unit, a marketing unit, a finance and accounting unit and an organisation and administration unit. In a typical WUP organisational structure, other units would include those for labour market policies (which include life-long learning as well as labour market services), research and analysis (responsible for PES operational statistics as well as a regional labour market observatory function), and separate units for ESF labour market programmes, ESF social integration projects, ESF entrepreneurship projects, and ESF education and training projects. This suggests that the PUP staff mainly support placement and related functions but a large proportion - possibly more than half - of the WUP staff implement education/training (not mainly targeted on the unemployed) and local economy and enterprise development programmes.

61. WUP and PUP staff costs are in principle borne by self-governments within the limits approved by the sejmiks or poviat councils. According to law, however, labour offices may grant additional wage allowances to their staff, financed from Labour Fund resources. ${ }^{28}$ These wage allowances should reflect the acquired grade of the professional license $\mathrm{e}^{29}$ or the level of professional qualifications, and the quality of delivered work. ${ }^{30}$ These arrangements, together with the standards for labour market services issued by the Minister in 2007, reflect the efforts of the central government to improve the quality and efficiency of PES performance.

28. The PUP and WUP may devote up to $7 \%$ of their grant from the Labour Fund to wage supplements for their staff.

29. With respect to the placement officers and vocational counsellors.

30. Detailed criteria for determining wage supplements to individual WUP and PUP staff categories are defined in MPiPS (2006c). 
62. The PES in Poland faces extremely high staff turnover. In 2004 and 2005 around $50 \%$ of staff changed. In PUP the staff turnover was even higher, at around 60\%. In 2006 the situation somewhat improved but the staff turnover of more than $30 \%$ was still significant. Half of the leaving workers were previously PUP unemployed clients who were engaged by PUP in the framework of public works. When the subsidised periods expired, they usually left since their contracts were not prolonged (MPiPS, 2007a). Engaging the unemployed with inadequate qualifications might have undermined the professionalism of main PES services. Moreover due to the short-term character of these engagements the PUP might have been (and most probably were) reluctant to invest in improving their professional qualifications and skills. As from 2006, the PUP are no longer allowed to hire staff in the framework of public works.

63. According to PUP directors the high staff turnover is mainly caused by poor wage conditions that PUP may offer (MPiPS, 2007a). However when looking at the main reasons for staff separations (Table 9) in all reported years, only a fraction (3-6\%) of PUP employees left at their own request, i.e. most probably due to uncompetitive salaries. By contrast, up to $50 \%$ of the employees who left the WUP in 2005 and 2006 did so at their own request. Objectively, they had less wage-related motives to leave, as the average wage of the professional staff in WUP exceeded PLN 3100 as compared with the PUP average wage of PLN 1600 (MPiPS, 2007a). Only one-fifth of WUP directors complained about difficulties concerning wage policy (MPiPS, 2007d).

Table 9. Staff separations from poviat and voivodeship labour offices by reason for leaving, 2003-2006

\begin{tabular}{|c|c|c|c|c|c|c|c|c|c|c|c|c|}
\hline \multicolumn{13}{|c|}{ Units and percentages } \\
\hline & \multicolumn{3}{|c|}{2003} & \multicolumn{3}{|c|}{2004} & \multicolumn{3}{|c|}{2005} & \multicolumn{3}{|c|}{2006} \\
\hline & Total & WUP & PUP & Total & WUP & PUP & Total & WUP & PUP & Total & WUP & PUP \\
\hline $\begin{array}{l}\text { Total number of dismissals } \\
\text { Of which: }\end{array}$ & 8914 & 175 & 8739 & 10818 & 295 & 10523 & 11798 & 246 & 11552 & 5798 & 277 & 5521 \\
\hline $\begin{array}{l}\text { Due to termination of an active } \\
\text { labour market programme }\end{array}$ & 4660 & 36 & 4624 & 5048 & 48 & 5000 & 5459 & 15 & 5444 & 1016 & 11 & 1005 \\
\hline Percentage of all dismissals & 52.3 & 20.6 & 52.9 & 46.7 & 16.3 & 47.5 & 46.3 & 6.1 & 47.1 & 17.5 & 4.0 & 18.2 \\
\hline $\begin{array}{l}\text { Due to restructuring of employment } \\
\text { in the labour office }\end{array}$ & 372 & 21 & 351 & 246 & 10 & 236 & 166 & 1 & 165 & 64 & 5 & 59 \\
\hline Percentage of all dismissals & 4.2 & 12.0 & 4.0 & 2.3 & 3.4 & 2.2 & 1.4 & 0.4 & 1.4 & 1.1 & 1.8 & 1.1 \\
\hline At the employee's request & 305 & 55 & 250 & 401 & 116 & 285 & 510 & 123 & 387 & 492 & 137 & 355 \\
\hline Percentage of all dismissals & 3.4 & 31.4 & 2.9 & 3.7 & 39.3 & 2.7 & 4.3 & 50.0 & 3.4 & 8.5 & 49.5 & 6.4 \\
\hline Other non-specified reasons & 3577 & 63 & 3514 & 5123 & 121 & 5002 & 5663 & 107 & 5556 & 4226 & 124 & 4102 \\
\hline Percentage of all dismissals & 40.1 & 35.8 & 40.2 & 47.4 & 41.0 & 47.5 & 48.0 & 43.5 & 48.1 & 72.9 & 44.7 & 74.3 \\
\hline
\end{tabular}

Source: MPiPS (2007d); and author's calculations.

64. Until 2005, about half of the separations from the PUP were due to termination of participation in an active labour market programme. In 2006, as hiring under the intervention works programme ceased, separations for this reason fell sharply and the majority of separations were for other, non-specified reasons. Among PUP this group represented $74 \%$ of separations in 2006 . It would be interesting to analyse further the reasons lying behind such significant losses of human capital.

\section{B. Public expenditure on the PES}

65. Active labour market programmes in Poland are financed from multiple sources, namely the Labour Fund, the state budget, the budgets of self-governments, and European Structural Funds, particularly the ESF. In principle PUP and WUP operational costs are born by the respective territorial self-governments ${ }^{31}$ and other active labour market programmes and unemployment insurance benefits are financed from the Labour Fund.

31. Although a part of PES administrative costs are also financed from the LF, such as wage bonuses for certain groups of PUP staff, labour costs of the WUP staff implementing the ESF projects, WUP and PUP IT equipment, costs of the PES staff training, etc. 
66. Although a substantial majority of tasks in the area of employment promotion is delivered by the self-government structures, this is not reflected in the structure of financing. A major part of resources comes from the fund administered by the state, and almost $90 \%$ of its expenditure is determined by law (RWI, 2005). Such a system in fact limits the actual independence of territorial self-governments and makes labour market policies very passive (MPiPS, 2007a; and RWI, 2005).

\section{The Labour Fund}

67. The Labour Fund (LF) was established in 1989 as a state earmarked fund managed by the Minister responsible for labour issues. LF revenues come from employer contributions levied for people employed for at least the minimum wage, ${ }^{32}$ from the contributions of self-employed people ${ }^{33}$ and EU resources, although these have declined in 2008 (Table 10). ${ }^{34}$ Before 2004, the LF also received subsidies ${ }^{35}$ from the state budget.

Table 10. Labour Fund planned revenues, 2006-2008

Percentages

\begin{tabular}{lrrc}
\hline Type of revenue & $\mathbf{2 0 0 6}$ & $\mathbf{2 0 0 7}$ & Plan 2008 \\
\hline Total & $\mathbf{1 0 0 . 0}$ & $\mathbf{1 0 0 . 0}$ & $\mathbf{1 0 0 . 0}$ \\
Contributions & 90.6 & 91.1 & 94.8 \\
EU resources & 7.6 & 7.5 & 3.8 \\
Other & 1.8 & 1.4 & 1.4 \\
\hline
\end{tabular}

Source: MPiPS (2006a, and 2007b).

68. When labour offices were made directly responsible for the delivery of all services in 2004, the LF's role significantly changed. Although it has retained the status of a state fund managed by a representative of the central government, the LF now allocates only a small fraction of its financing to activities managed directly by the state. Almost all its resources are allocated to the self-governments which use them under their own responsibility (MPiPS, 2007a). The allocation of resources to voivodeships is determined at the central level according to an established algorithm and allocations within the voivodeships are decided by sejmiks (Box 2).

69. The LF represents the main source of financing for unemployment insurance benefits and active measures aimed at preventing unemployment. ${ }^{36}$ From its creation in 1989 until 2006 the expenditures on

32. Employer contributions (at the level of $2.45 \%$ of the assessment base) are collected by the Social Insurance Institution (ZUS) and are deposited on a separate bank account (MPiPS, 2004a).

33. Excluding small farmers.

34. EU resources mean for instance the resources for delivering EURES services in Poland.

35. The Labour Fund had often experienced financial problems: state subsidies were 38.7\% of its total revenues in 2002, 40.2\% in 2003 and 15.6\% in 2004 (MPiPS, 2007a).

36. Other types of expenditure from the Labour Fund include costs of regional programmes including programmes co-financed from the ESF; costs of training of the PES staff; labour costs of the PUP staff engaged in projects co-financed from the ESF; spending on the tasks related to the participation of the labour offices in the EURES network; wage bonuses for the PES staff; costs of the job-club equipment; training of the PES and Voluntary Work Corps staff; training and travel costs incurred by the members of the employment boards; communications and other administrative costs; and costs of bank services including any interest (Questionnaire responses and the 2004 Act). According to some analyses (e.g. MPiPS, 2007a), in order to make the administration of the LF more transparent and efficient, the LF should stop allocating funds for the administrative costs of public employment services, especially the 
passive labour market programmes had always exceeded allocations for active programmes (MPiPS, 2007a). In 2007, LF active spending was for the first time higher than spending on income support for the unemployed. Such a positive spending ratio was also planned in the LF budget for 2008.

\section{Box 2. The system of allocations from the Labour Fund}

The Minister for labour and social policy allocates LF resources to individual voivodeships according to established algorithms. There is a special algorithm for each group of tasks. Thus, for instance, amounts allocated for the financing of tasks related to employment promotion and vocational activation at a poviat level depend on variables such as the numbers of registered unemployed above 50 years of age and below 25 years of age, the level of unemployment, and the amount of resources allocated in previous year by that voivodeship for the implementation of ESF projects. This determines limits for spending on training of the unemployed, subsidised employment, public works, and employment restructuring.

The algorithm determining limits for tasks delivered at a voivodeship level is less complicated. This covers e.g. expenditures on organising local partnerships, training of the employment board members, wage supplements for the PES staff and their training, the development and dissemination of vocational information, labour market research, etc. The limits on resources to be allocated for these categories of tasks basically depend on the individual voivodeship's share of the total number of PUP nationwide.

In terms of procedures, the Minister informs the marszałeks about the limits allocated for their voivodeship. At a voivodeship level, the sejmik decides on the criteria according to which the allocated limit shall be spent. The marszałeks then report to the Minister what proportion of resources they have determined for tasks to be delivered by the poviat self-governments. It is the Minister who notifies the poviat starostas about the limits they have at the disposal. Thus, the overall limit of resources for a particular voivodeship is determined at the central level according to the established algorithm, but the internal allocations within the voivodeships are decided by the sejmiks.

The resources for financing unemployment insurance benefits and other mandatory allowances are allocated according to anticipated needs. Often, the allocated amounts exceed the actual needs, in which case the PUP may ask the Ministry for permission to shift spending towards active labour market programmes.

A part of the LF resources is set aside for the so-called Minister's reserve. From his/her own initiative, or upon a request from a voivodeship marszałek, the Minister may use the reserve for granting additional amounts to those voivodeship and/or poviat self governments where the labour market situation significantly deteriorated, or where highly efficient employment restructuring, regional or ESF programmes are being implemented.

The limits allocated to voivodeships and poviats may be increased by reallocations of unspent LF resources. Marszałeks may ask the Minister to reduce the limit allocated to their voivodeships and/or poviats if the spending anticipated in the budget year is not feasible. These amounts are then shifted to another poviat or are kept within the Minister's reserve.

Source: MPiPS (2004d).

70. Thanks to the exclusion of pre-retirement benefits from LF expenditures in 2005, the LF succeeded in radically increasing its financing of active labour market programmes as well as reducing its indebtedness, which in 2004 amounted to PLN 4.3 billion. The relief was so substantial ${ }^{37}$ that it was possible to increase active spending even in a situation when the state subsidies were stopped (MPiPS, 2007a). Tables 11 and 12 show the structure of expenditure in recent years.

labour offices that fall under the competence of the self-governments. At the same time, bank interest should no longer be paid from the LF.

37. Expenditure on pre-retirement benefits during 2000-2004 was $28.8 \%$ higher than expenditure on unemployment insurance benefits, and in 2004 it represented $38.7 \%$ of total LF expenditure. In general the outlays on financial benefits have been decreasing, from $90.2 \%$ of total LF expenditure in 2000 to $82.5 \%$ in 2004 and 58\% in 2005 (MPiPS, 2007a). 
Table 11. Structure of planned expenditure from the Labour Fund, 2006-2008

Percentages $^{a}$

\begin{tabular}{lrrrrc}
\hline Type of expenditure & $\mathbf{2 0 0 6}$ & $\mathbf{2 0 0 7}$ & $\begin{array}{c}\text { Index } \\
\mathbf{2 0 0 7 / 2 0 0 6}\end{array}$ & Plan 2008 & $\begin{array}{c}\text { Index } \\
\mathbf{2 0 0 8 / 2 0 0 7}\end{array}$ \\
\hline Total & $\mathbf{1 0 0 . 0}$ & $\mathbf{1 0 0 . 0}$ & - & $\mathbf{1 0 0 . 0}$ & - \\
Benefits and allowances $^{\text {Activation bonus }}{ }^{b}$ & 52.9 & 41.2 & -11.7 & 35.0 & -6.2 \\
Integration allowance $^{c}$ & 0.8 & 0.7 & -0.1 & 2.0 & 1.3 \\
ALMP programmes $^{d}$ & 0.1 & 0.1 & 0.0 & 0.3 & 0.2 \\
PES staff $^{\text {r }}$ & 37.4 & 50.6 & 13.2 & 52.6 & 2.0 \\
Other $^{f}$ & 2.1 & 2.1 & 0.0 & 3.5 & 1.4 \\
Capital expenditures & 6.0 & 4.6 & -1.4 & 5.8 & 1.2 \\
\hline
\end{tabular}

- Not relevant.

a) Indexes are calculated as the difference between 2007 percentages (respectively 2008) and 2006 percentages (respectively 2007).

b) Activation allowance is granted to people who, in the course of receiving the unemployment insurance benefit, start employment or self-employment.

c) Integration allowance is granted to unemployed social-safety-net beneficiaries who participate in Social Integration Centres - see section on Activation of social-safety-net beneficiaries.

d) In the LF budget this item is entitled as active forms of solving unemployment.

e) The LF allocations for the PES staff include: i) partial financing of the PUP staff labour costs, ii) wage bonuses for certain groups of staff in labour offices and OHP, and iii) labour costs of the WUP staff involved in projects co-financed from the ESF.

f) Other expenditure includes: interest payments on the LF bank loans taken out in 2000-2004 (but in 2008, the loans being fully repaid, interest payments are zero), administrative costs, delivery of vocational counselling, labour market analyses, expertises, job clubs equipment, the PES IT system, costs of collecting contributions for the LF, costs of the PES staff training, costs of local partnerships and EURES tasks, social security of farmers, travel and training costs of the employment board members, costs of the external audit of the ESF projects, remittance of unduly paid benefits, costs of judiciary proceedings, executions and interests.

Source: MPiPS (2006a, and 2007b); and author's calculation.

Table 12. Structure of planned expenditure from the Labour Fund on active programmes and instruments, 2006-2008

Millions of zlotys (PLN) and percentages ${ }^{a}$

\begin{tabular}{|c|c|c|c|c|c|}
\hline Type of expenditure & 2006 & 2007 & $\begin{array}{c}\text { Index } \\
2007 / 2006\end{array}$ & Plan 2008 & $\begin{array}{c}\text { Index } \\
2008 / 2007\end{array}$ \\
\hline Training & 153 & 225 & 147.1 & 225 & 100.0 \\
\hline Intervention works & 180 & 200 & 111.1 & 200 & 100.0 \\
\hline Public works & 115 & 150 & 130.4 & 150 & 100.0 \\
\hline Socially purposeful works & 25 & 33 & 132.0 & 33 & 100.0 \\
\hline Self-employment allowances & 450 & 560 & 124.4 & 560 & 100.0 \\
\hline Allowances for the equipment of the work place & 200 & 250 & 125.0 & 250 & 100.0 \\
\hline Scholarships during trial period & 650 & 1000 & 153.8 & 1086 & 108.6 \\
\hline Scholarships during vocational training & 230 & 315 & 137.0 & 350 & 111.1 \\
\hline Scholarship during continuous education & 10 & 12 & 120.0 & 12 & 100.0 \\
\hline Reimbursement of the labour costs for young workers & 180 & 185 & 102.8 & 185 & 100.0 \\
\hline Amortisation of loans & 15 & 15 & 100.0 & 12 & 80.0 \\
\hline Other $^{b}$ & 42 & 55 & 131.0 & 65 & 118.2 \\
\hline Total & 2250 & 3000 & 133.3 & 3128 & 104.3 \\
\hline
\end{tabular}

a) Indexes are calculated as the relative difference between 2007 (respectively 2008) and 2006 (respectively 2007) in percentages.

b) Other refers to travel and accommodation costs, child care or care for a dependant person, social security contributions, medical assessments.

Source: MPiPS (2006a, and 2007b). 


\section{Self-government budgets}

71. As explained above, PUP and WUP operational costs (staff labour costs, overheads and other administrative expenditures) are primarily financed by the relevant levels of self-government. ${ }^{38}$ The allocations are approved by the sejmik or the poviat council and in general depend on the overall financial situation of the respective territorial unit, their involvement in the implementation of investment projects and, last but not least, on political decisions in poviat councils and sejmiks about local priorities. In 2005 the spending on WUP operation represented $2.6 \%$ of total voivodeship expenditures. With respect to PUP, where the main assistance to the unemployed is delivered, the spending was as low as $0.9 \%$ of total poviat expenditures.

72. The above data show that local governments, especially at a poviat level, allocate tiny proportions of local budgets to labour office operation. On the other hand, over the last five years the dynamics of wage expenditures both in PUP and WUP has increased and has exceeded the growth index in the whole public sector (MPiPS, 2007a).

73. The level of poviats' spending on PUP operation expressed in relation to the number of inhabitants differs significantly with no evident correlation with the poviats' socio-economic situation. When related to the number of unemployed the gaps are somewhat narrower but still significant. They might reflect different approaches and methods used by individual PUP in delivering labour market services (MPiPS, 2007a).

\section{State budget}

74. The management of the state budget resources allocated for labour market policies is shared between the Minister and voivodes. In 2005 the state budget spending on tasks related to employment promotion and delivery of labour market services represented $0.1 \%$ of all state budget expenditures. Until 2004, a significant part of the state budget expenditures on labour market issues represented the subventions for the Labour Fund.

\section{EU resources}

75. Until 2007, Poland had not fully used the potential offered by the European structural funds for financing of active labour market policies and functioning of public employment services (MPiPS, 2007a). For the current programming period 2007-2013, the Polish Government intended to adapt the strategies and mechanisms accordingly.

\section{Public expenditure on public employment service and administration}

76. Because PUP and WUP operational costs are mainly financed by local budgets, expenditure depends mainly on the financial situation in a particular voivodeship or poviat and on local political decisions. However, since the Central Government issued detailed PES standards, ${ }^{39}$ in 2007 the self-governments have been forced to allocate sufficient resources to comply with these centrally determined standards.

38. Although the situation is somewhat complicated by the fact that part of WUP and PUP "own administrative expenditures" are financed from the Labour Fund.

39. MPiPS (2007e) set standards for labour market services and MPiPS (2007i) specified detailed conditions (see a previous note for a listing of some of these) for the delivery of labour market services by public employment services. The PES institutions had to comply with requirements concerning staff numbers before 30 June 2008. 
77. Table 13 shows public expenditure on public employment services and administration in 2005 and 2006. Total expenditure on labour market services increased in 2006 as compared to 2005 by significant $51 \%$, due to a $55 \%$ increase for services provided by local PES institutions. Two factors behind this increase were the inclusion in the 2006 data of an earmarked subsidy to entities outside the public sector that implement projects co-financed by the European Social Fund, ${ }^{40}$ and growth in the wages of PUP and WUP employees. The Ministry also supposes that the improved macroeconomic situation brought higher revenues from local taxes that enabled the self-governments invest more in PES (MPiPS, 2008b). Because the self-governments should have complied with the new PES delivery standards before $1^{\text {st }}$ July 2008, we may expect in 2007 and 2008 further increases in spending on this item.

Table 13. Public expenditure on PES and administration functions, 2005 and 2006 Millions of zlotys (PLN), millions of euros (EUR) and percentages ${ }^{a}$

\begin{tabular}{|c|c|c|c|c|c|}
\hline & \multicolumn{2}{|c|}{2005} & \multicolumn{2}{|c|}{2006} & \multirow{2}{*}{$\begin{array}{c}\text { Index } \\
2006 / 2005\end{array}$} \\
\hline & PLN & EUR & PLN & EUR & \\
\hline $\begin{array}{l}\text { LM services total } \\
\text { Of which }\end{array}$ & 678.74 & 168.73 & 993.68 & 255.07 & 1.51 \\
\hline Services provided by local PES ${ }^{b}$ & 638.63 & 158.75 & 956.27 & 245.46 & 1.55 \\
\hline Job clubs $^{c}-$ Training in job-search skills & 1.44 & 0.36 & 1.24 & 0.32 & 0.89 \\
\hline Job clubs $^{c}-$ Activation tutorials & 6.66 & 1.66 & 6.70 & 1.72 & 1.04 \\
\hline Vocational counselling & 8.65 & 2.15 & 9.25 & 2.38 & 1.11 \\
\hline Financing of travel costs ${ }^{d}$ & 23.36 & 5.81 & 20.22 & 5.19 & 0.89 \\
\hline
\end{tabular}

a) Indexes are calculated as the relative difference between 2006 and 2005 in percentages.

b) Spending on this item includes remuneration of all employees, operational costs and investments in WUP and PUP. Although OHP too belong to PES institutions in Poland, they are not included in the LMP database. In 2005, the remuneration of the front-line placement and related staff (see Tables 4 to 6 above) is estimated at PLN 64.906 million, i.e. EUR 16.82 million. These staff represented $17 \%$ in 2005 , and $20 \%$ in 2006 of all employees. Staff remuneration is estimated based on staff numbers and the average remuneration of PUP and WUP staff.

c) This item only covers job clubs established by PUP. Data on spending include the costs of equipment financed from the Labour Fund, and the remuneration of job-club leaders financed from self-government budgets (which is estimated to be PLN 2021.1 thousand in 2005 and PLN 3388.8 thousand in 2006). The financing from self-government budgets of other operational costs is not included.

d) This item also includes expenditure on financing accommodation costs of the unemployed who took up employment or other paid work, apprenticeship, vocational training at a workplace or training outside their place of permanent residence.

Source: Eurostat (2008); MPiPS (2008b); and author's calculations.

\section{PES workload indicators}

\section{Registered vacancies and placements}

78. Polish statistics distinguish between vacancies (wolne miejscia zatrudnienia) and "job offers" (oferty pracy). A "job offer" means a vacancy which the employer intends to fill and for that purpose is seeking a suitable candidate. Employers in Poland are obliged to notify PUP about their job offers as well as vacancies. ${ }^{41,42}$ The information about notified vacancies for which employers are not currently seeking

40. The data for "PES and administration" functions refer, strictly speaking, to publicly-financed employment services and not only services that are delivered by public sector employees and institutions.

41. Notification of a job offer shall contain the following data: concerning the employer: name, address, phone number, name of the contact person delegated by the employer, legal form, fiscal identification number, the kind of economic activity according to the official classification, number of employed people; and concerning the notified employment or other paid work: name and code of the occupation according to the official classification, name of the job position, number of vacancies including number of vacancies for disabled people, place of work performance, type of work contract, organisation of the working time, 
candidates is further used for analysing occupational requirements on the labour market and for planning of training policies. The Ministry issues quarterly statistics for job offers according to their source, i.e. public or private sectors, with separate information for seasonal work.

79. In the statistics used by PUP a job offer is defined as a vacant job or a vacant place offered for the purpose of one of the active labour market programmes, i.e. vocational preparation at a workplace, intervention works, public works, socially useful works, work experience, or other form of work that is available for candidates referred by PUP.

80. From 2002 the number of job offers notified to the PUP has been increasing for both subsidised and non-subsidised work. More job offers have been coming from both the public as well as private sectors. Along with higher exits from the unemployment registry the number of registered unemployed for 1 job offer has thus been decreasing. While in 2002 there were 61 registered unemployed people for 1 notified job offer, in 2006 the ratio dropped to 23 (MPiPS, 2007k) and in 2007 further to 15 (Table 14).

Table 14. Registered job offers, 2000-2007

\begin{tabular}{|c|c|c|c|c|c|}
\hline \multicolumn{6}{|c|}{ Units } \\
\hline & \multirow{2}{*}{$\begin{array}{c}\text { Registered } \\
\text { job offers notified }\end{array}$} & \multicolumn{2}{|c|}{ Of which } & \multirow{2}{*}{ Total stock } & \multirow{3}{*}{$\begin{array}{c}\text { Average number } \\
\text { of registered unemployed } \\
\text { per job offer }{ }^{a}\end{array}$} \\
\hline & & For subsidised work & From the public sector & & \\
\hline & \multicolumn{3}{|c|}{ In the reported period } & $\overline{\text { At end of period }}$ & \\
\hline 2000 & 607705 & 241155 & 120519 & 5715 & 45 \\
\hline 2001 & 465693 & 117279 & 82659 & 5322 & 65 \\
\hline 2002 & 555563 & 198878 & 122421 & 8315 & 61 \\
\hline 2003 & 739355 & 384178 & 204511 & 10328 & 46 \\
\hline 2004 & 793951 & 339334 & 193786 & 13235 & 40 \\
\hline 2005 & 885236 & 371990 & 210563 & 17542 & 33 \\
\hline 2006 & 1117165 & 414814 & 266487 & 30707 & 23 \\
\hline 2007 & 1242202 & 477592 & 296515 & 44484 & 15 \\
\hline
\end{tabular}

a) Average number of registered unemployed for one notified job offer was calculated according to the following formula: (registered unemployed, number at the end of the preceding year + number at the end of the given year)/2

(number of job offers notified in the given year/12 + stock of job offers at the end of the preceding year)

Source: www.psz.praca.gov.pl; MPiPS (2007k); and author's calculations.

81. At the same time, the number of unfilled job offers has constantly been rising. This trend may reflect the general difficulties that the employers face in filling vacancies (MPiPS, 2007k) as well as of PES inability to provide suitable candidates for work. Table 15 shows the number of unfilled job offers at the end of each years. For years 2001-2004 unfilled job offers were structured according to the criterion of subsidised/non-subsidised work in the publication. From 2005 onwards the statistics are broken down according to different criteria.

82. Job offers are publicised on PUP announcement boards and are simultaneously inserted in the internet database of job offers that is administered by the Ministry. The date for the "realisation of a job

amount and system of the remuneration for work, date of take-up, requirements concerning the unemployed person or the jobseeker, qualification and skill requirements concerning the candidates for work, proposed range of publicising of the job offer (MPiPS, 2007i).

42. Employers are also obliged to verify the status of every person that they hire and inform the PUP in writing within five days about every registered unemployed person that they have hired. 
offer" ${ }^{\prime 43}$ and the period for which it should be kept in the PUP database is specified with the employer. Placement officers should check the validity of job offers at a frequency agreed with the employer or at least once in three days. Job offers should be removed from the database when the placement officer has three times failed to contact the employer or a person delegated by him/her. A job offer should always be verified before referring a PUP client to apply for it (MPiPS, 2007e).

Table 15. Notified job offers and job offers unfilled for more than a month, 2001-2007

Units

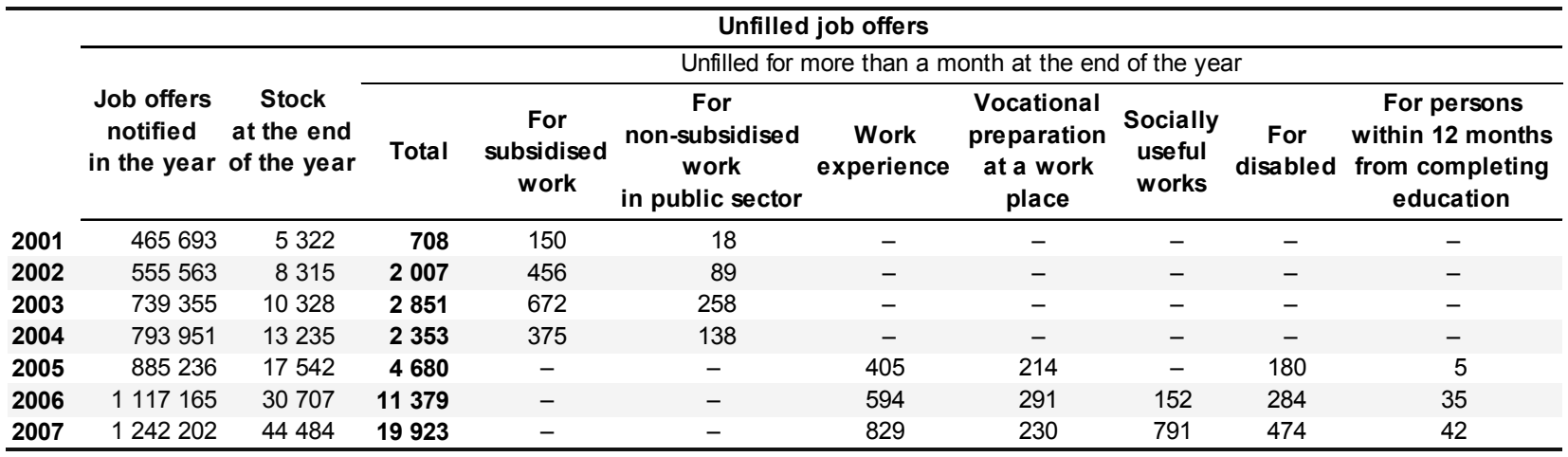

- Not applicable.

Source: www.psz.praca.gov.pl.

83. Referred people receive a referral-to-work card and are required to confirm by a signature that they were informed about implications resulting from refusing suitable work or failing to report to PUP about the result of job interview. Employers are requested to note in the card the result of the interview and possible reasons for not hiring the referred candidate.

84. The Polish Central Statistical Office does not distinguish between entries to work by the registered unemployed that resulted from PES assistance and those resulting from their individual job-search activities. The statistics report total entries to work with subcategory data for subsidised work and seasonal work (Table 16). The share of take-ups of work in the total outflow has been steadily decreasing from $50.1 \%$ in 2000 to $41.5 \%$ in 2007 : this reflects an increase in the share of other outflow destinations. The share of take-ups of seasonal work in total entries to work has since 2002 (when it was $12.6 \%$ ) had a downward tendency (reaching $6.9 \%$ in 2007) while movements in the number of placements in subsidised jobs have been uneven across the years.

85. More detailed information is obtained by the monitoring of placement services that is undertaken by individual PUP. Because this information is not collected at a national level, we only present data obtained from the Warsaw Labour Office ${ }^{44}$ (Table 17). These data are not representative for the PES in Poland as a whole (the Warsaw office handles about $2 \%$ of the national stocks and flows of registered unemployment), but they provide at least some idea about the efficiency of placement services delivered by labour offices. In 2006, placements of registered unemployed into work with the assistance of the Warsaw Labour Office were $84 \%$ of all exits to employment and $37 \%$ of total outflows from registered unemployment. And $77.1 \%$ of notified job offers were filled with the assistance of the Warsaw Labour Office by people registered as unemployed or jobseekers.

43. The term "realisation of a job offer" used in the Polish legislation means publicising a job offer and delivering other services aimed at filling it with a suitable candidate.

44. The "Warsaw Labour Office" refers to Urzqd pracy m. st. Warszawy (Labour Office of the Capital City of Warsaw). In compliance with the Act on the City of Warsaw, Warsaw is not a poviat and its districts are not gmina but dzielnica. Nevertheless, the Labour Office of the Capital City of Warsaw has the same competences as poviat labour offices (PUP) and dzielnica has similar competences as gmina. 
Table 16. Outflows from the unemployment registry to work, 2000-2007

\begin{tabular}{|c|c|c|c|c|c|c|c|c|c|}
\hline \multicolumn{10}{|c|}{ Units } \\
\hline & & 2000 & 2001 & 2002 & 2003 & 2004 & 2005 & 2006 & 2007 \\
\hline \multicolumn{2}{|l|}{ Inflow of job offers } & 607705 & 465693 & 555563 & 739355 & 793951 & 885236 & 1117165 & 1242202 \\
\hline \multicolumn{2}{|l|}{ Inflow of unemployed } & 2475876 & 2476217 & 2550186 & 2642236 & 2684128 & 2793181 & 2692351 & 2491242 \\
\hline Outflow of unemployed & Total & 2123005 & 2063737 & 2448284 & 2683520 & 2860201 & 3019782 & 3155941 & 3054079 \\
\hline \multirow[t]{3}{*}{ Due to take-up of work ${ }^{a}$} & Total & 1063937 & 1008812 & 1186917 & 1297344 & 1364580 & 1365790 & 1412799 & 1266439 \\
\hline & Subsidised work & 185995 & 85629 & 119233 & 263702 & 197969 & 186693 & 163019 & 185766 \\
\hline & Seasonal work & 125573 & 117661 & 149633 & 130032 & 135719 & 117184 & 111970 & 87028 \\
\hline \multicolumn{2}{|c|}{ Due to unproved availability for work } & 700969 & 746917 & 859631 & 857778 & 950523 & 993124 & 972176 & 949210 \\
\hline \multicolumn{2}{|l|}{ For other reasons ${ }^{b}$} & 358099 & 308008 & 401736 & 528398 & 545098 & 660868 & 770966 & 838430 \\
\hline
\end{tabular}

a) Take-ups of work represent total exit from the registry due to take-up of work regardless of whether the work was mediated by the PUP or based on individual job-search activities; the PUP have no statistics about the number of registered unemployed placed in work with the assistance of the PUP.

b) Other reasons include participation in a labour market programme, voluntary de-registration, take-up of study, completion of 60 (women)-65 (men) years of age, acquisition of old-age pension rights, acquisition of pre-retirement allowance rights and other non-specified reasons.

Source: www.psz.praca.gov.pl; and author's calculations.

Table 17. Placement statistics of the Warsaw Labour Office, 2006

\begin{tabular}{lc}
\multicolumn{1}{c}{ Units and percentages } \\
\hline Inflow of unemployed & 51583 \\
Outflow of unemployed & 60572 \\
Takes-up of work & 26586 \\
Percentage of total outflow & 43.9 \\
$\quad$ With the assistance of PUP & 22424 \\
$\quad$ Percentage of all take-ups of work & 84.3 \\
$\quad$ Percentage of total outflow & 37.0 \\
Number of notified job offers & 27409 \\
Percentage of notified job offers filled in with the assistance of the PUP & 77.1 \\
\hline
\end{tabular}

a) Covers the placements of both registered unemployed and registered jobseekers.

Source: WAW (2007); data obtained from the monitoring of placement services of the Labour Office of the Capital City of Warsaw; and author's calculations.

86. In spite of employers' obligation to notify, the vacancies captured by PUP represent only a fraction of all vacancies in the economy. Employers mainly notify vacancies in low-skilled jobs, whereas notifications of offers for high-skilled posts are limited as compared to the number of them in the whole economy. The structure of notified vacancies and job offers reflects the character of support offered by PUP (MPiPS, 2007c). The relatively high proportion of registered job offers filled by the Warsaw Labour Office (and possibly by other PUP, too) should be interpreted in light of this situation: the supply of job offers notified to PUP matches well with the supply of people referring to PUP for assistance. If the Warsaw Labour Office percentage of vacancies filled (77.1\%) is applied to all job offers notified in Poland in 2006 (1.117 million) and related to all annual hires in the economy (3.912 million), ${ }^{45}$ the estimated Polish PES market share in placement services would be $22 \%$.

45. As Poland has no statistics on the number of all hires in the economy we estimated it on the basis of the Labour Force Survey data on dependent employees: according to the LFS in $2006,4.3 \%$ of dependent employees have been with their current employer for less than one month and $10.2 \%$ for less than six months (based on the online OECD Employment database data for job duration) hence the monthly hiring rate (even when excluding very short-duration jobs) is at least $1.7 \%$ of the number of dependent employees per month. We estimated total monthly hiring rate at $3 \%$ (the average of $4.3 \%$ and $1.7 \%$ ), hence annual hiring rate was $36 \%$ in 2006. Based on the number of 10.866 million employees in 2006 we arrive at 3.912 million annual total hires of dependent employees in 2006. This is about twice the number of hires of full-time employees cited in CSO (2008b), 1.917 million in 2006, which refers only to full-time employees excluding seasonal and temporary employees and economic entities employing less than 10 people. 
However it should be kept in mind that the Warsaw labour market is relatively specific: if the PES share in filling vacancies is lower outside Warsaw, this estimate will overstate the true national market share.

\section{Job clubs and activation classes}

87. The PES in Poland complements its job-broking services with measures to motivate and assist independent job search. About 75000 PES clients, most of them unemployed, participated in job-search training and activation classes in 2006 (Box 3).

\section{Box 3. Job clubs in Poland}

Training in job-search strategies and related activation classes ${ }^{46}$ is delivered by job clubs established by PUP or their partner institutions such as gmina social assistance centres. ${ }^{47}$ Delivery of job-club services may also be outsourced to external providers. In 2006 there were 611 job clubs in operation, which assisted 75761 people. Most clients $(92.4 \%$ ) were unemployed. More than $86 \%$ of all job clubs were established within the PUP structures, and only one was operated by an external provider (see Table 18).

According to the standards issued in $2007^{48}$ a person may be referred to training in active job search once in two years. The training is delivered in groups not exceeding 14 people. It takes three weeks and consists of two parts:

- 40 hours of workshops in the form of separate thematic sessions delivered over 10 consecutive working days; and

- $\quad$ Practical job search performed over 5 consecutive working days and at least 15 hours of collective sessions, aimed at exchanging and debriefing of experience from the job-search activities, and mutual assistance in the course of job search.

Activation classes are delivered in the form of workshops for groups not exceeding 16 people. They may be preceded by individual interviews with vocational counsellors, placement officers or vocational development specialists, which help specify the scope of assignments that the person should undertake.

Training in active job search and activation classes are delivered by job-club leaders. In cases requiring specialised knowledge, the job-club leader may co-operate with other PUP staff or staff from the WUP Centre for Information and Vocational Guidance. MPiPS (2004a) defines job-club leader as one of the six main PES staff functions. Candidates for this function must provide evidence of least 12 months of work experience in the PES in the area of active job search.

In 2006, 132 people had a staff position as job-club leader, ${ }^{49}$ all of them employed in the PUP. In the PUP where the position of job-club leader was not filled, his/her tasks were delivered by other staff, most often by vocational counsellors "for whom job clubs were only one of many tasks" (MPiPS, 2007h). From July 2008, all PES institutions must employ at least one part-time job-club leader for every two full-time placement officers (MPiPS, 2007i).

The percentage of participants entering work as a result of job club activities in 2006 averaged $22.7 \%$. The percentage for training in active job search was slightly higher $(24 \%)$ than for activation classes $(22 \%)$. Interestingly, the job-club activities were significantly more beneficial to unemployed people than other jobseekers. From the total number of unemployed people who participated in the active job-search training $25 \%$ undertook work in the course of or after completing the training. With respect to the participating jobseekers the efficiency was quite low, at $2.9 \%$. More details about the efficiency of job-club activities are presented in Table 19.

Source: MPiPS (2004a); and www.psz.praca.gov.pl.

46. Before 2005 all activities delivered by job clubs were reported under a single category. From 2005 training in job-search skills and activation classes are reported as two individual categories of job-club activities (MPiPS, 2007h).

47. For more information about the functioning of job clubs established and/or operated by gmina social assistance centres see the section on Activation of social-safety-net beneficiaries.

48. Regulation of the Minister on detailed conditions of delivering labour market services by the public employment services (MPiPS, 2007i).

49. In 2005, 102 job-club leader positions were occupied. 
Table $18 . \quad$ Job clubs in 2006

Units

\begin{tabular}{|c|c|c|c|c|c|c|c|c|}
\hline & & \multirow{2}{*}{$\begin{array}{l}\text { Number } \\
\text { of job clubs }\end{array}$} & \multirow{2}{*}{$\begin{array}{c}\text { Number } \\
\text { of participants } \\
\text { in training }\end{array}$} & \multicolumn{2}{|c|}{ Of which } & \multirow{2}{*}{$\begin{array}{c}\text { Number } \\
\text { of participants } \\
\text { in activation classes }\end{array}$} & \multicolumn{2}{|c|}{ Of which } \\
\hline & & & & Unemployed & Jobseekers & & Unemployed & Jobseekers \\
\hline \multicolumn{2}{|l|}{ Total } & 611 & 11568 & 10977 & 591 & 64193 & 59001 & 5192 \\
\hline \multirow{3}{*}{$\begin{array}{l}\text { Of which } \\
\text { job clubs } \\
\text { operated by }\end{array}$} & The PUP & 525 & 8920 & 8775 & 145 & 49016 & 47334 & 1682 \\
\hline & Partner institutions & 85 & 2648 & 2202 & 446 & 9080 & 6687 & 2393 \\
\hline & External providers & 1 & 0 & 0 & 0 & 267 & 256 & 11 \\
\hline \multicolumn{2}{|c|}{$\begin{array}{l}\text { WUP centres for information } \\
\text { and planning of vocational career }\end{array}$} & .. & .. & .. & .. & 5830 & 4724 & 1106 \\
\hline
\end{tabular}

Data not available.

Source: MPiPS (2007h).

Table 19. Job club participant starts, completions and outcomes, 2006

Units and percentages

\begin{tabular}{|c|c|c|c|}
\hline & \multirow{2}{*}{ Total } & \multicolumn{2}{|c|}{ Of which } \\
\hline & & Jobseekers & Unemployed \\
\hline \multicolumn{4}{|c|}{ Training in active job search } \\
\hline Started training in active job search & 12148 & 614 & 11534 \\
\hline Participated in training in active job search & 11568 & 591 & 10977 \\
\hline Completed training in active job search & 11075 & 554 & 10521 \\
\hline $\begin{array}{l}\text { Undertook work while or after completing t } \\
\text { in active job search }(\%)^{a, b}\end{array}$ & 23.8 & 2.9 & 24.9 \\
\hline $\begin{array}{l}\text { Started vocational training after completin } \\
\text { in active job search }(\%)^{a}\end{array}$ & 11.6 & 1.0 & 12.2 \\
\hline \multicolumn{4}{|c|}{ Activation classes } \\
\hline Participated in activation classes & 64186 & 5192 & 58786 \\
\hline $\begin{array}{l}\text { Undertook work while or after completing } \\
\text { activation classes }(\%)^{b}\end{array}$ & 21.6 & 1.3 & 23.2 \\
\hline $\begin{array}{l}\text { Started vocational training while or after cc } \\
\text { activation classes }(\%)\end{array}$ & 9.3 & 0.9 & 10.1 \\
\hline
\end{tabular}

a) Calculated from the number of people who participated in but did not necessarily complete the training.

b) Calculated from the totals of 2749 job-club participants and 13838 activation class participants who "undertook work" according to MPiPS (2007h). The data in fact refer to de-registrations, some of which may arise from inflows to inactivity and transfers to other PUP, and are likely to somewhat overstate the true numbers.

Source: MPiPS (2007h); and author's calculations.

\section{Unemployment insurance benefits}

\section{A. $\quad$ Eligibility criteria}

88. Entitlement to the unemployment insurance benefit (UI benefit) depends on the claimant's employment history. A person is entitled to UI benefit if over the period of the last 18 months he or she was employed (i.e. with standard employee status) for at least 365 days or undertook other recognised paid 
work or self-employment. ${ }^{50}$ In order to claim his or her entitlement, the person must register with the PUP in his/her place of residence. The UI benefit is then granted when within seven days ${ }^{51}$ from registration the PUP has failed to offer a suitable job or other paid work, or participation in any of the following active labour market programmes: work experience, vocational preparation at a work place, intervention works or public works (MPiPS, 2004a).

89. Beneficiaries who undertook employment or other paid work before expiry of their UI entitlement which lasted less than 365 days may draw the remaining part of their entitlement if they re-register within 14 days of termination of that employment or work. ${ }^{52}$ Unemployed people may always draw the remaining part of their UI entitlement if, on the date of re-registration, they fulfil the required employment periods.

90. People eligible for the retirement pension, disability pension, and sickness or maternity allowance cannot register as unemployed ${ }^{53}$ and are not entitled to the UI benefit. People receiving the training allowance $^{54}$ may continue receiving the UI benefit. The period receiving the training allowance does not reduce the remaining period of entitlement to passive receipt of benefit, but it does not count towards the months of contributions needed to start a new period of UI benefit. The benefit entitlement is also postponed (not reduced) when a person participates in other types of active labour market programmes during which the UI benefit is not granted. The benefit entitlement is postponed (not reduced) for 90 days for people who within the last 6 months voluntarily left employment, and for 180 days for people who were dismissed for fault. Unjustified refusal of a suitable employment and/or a labour market programme offered by a PUP leads to de-registration and postponement (not reduction) of UI entitlement for 90 days.

91. Benefit periods vary across the country and are determined according to the unemployment rate in the respective poviat. Specific periods are defined for some groups of the unemployed. The benefit period is 6 months in poviats where the unemployment rate is lower than $125 \%$ of the national average; 12 months in poviats with the unemployment rate exceeding $125 \%$ of the national average, and for people over 50 years of age who have at least 20 years of tenure; and 18 months in poviats with a more-than-a-double-national-average unemployment rate and for people who have at least 20 years of tenure or maintain at least one child below 15 years of age, when also their spouse is unemployed with an expired UI entitlement. ${ }^{55}$ According to RWI (2005) the diversification of benefit periods has made some people move to regions where unemployment is higher rather than the opposite way.

50. Compulsory military service, maternity leave, periods of receiving disability pension due to incapacity to work, sickness benefit, training allowance, rehabilitation allowance, other periods of contributing to the Labour Fund and periods when the person received compensation for unduly terminated work are recognised as substitute employment periods for the purpose of determining the entitlement to the unemployment insurance benefit.

51. When a claimant fails to document required employment periods within seven days from registration, the UI benefit will be paid from the day of documenting the periods and for a period determined according to standard criteria.

52. The person is of course required to notify the PUP of taking up the employment or other paid work, and document the employment periods. These arrangements also apply to people who undertook training or work experience organised by entities other than a PUP.

53. However, they may register as jobseekers and benefit from the labour market services provided by PUP such as placement, job-search assistance and vocational counselling.

54. Training allowance is granted to the registered unemployed when they participate in a training referred by a PUP.

55. Although unemployment insurance benefits are time-limited, health insurance coverage is provided from public funds for the unemployed who are registered at a PUP but not entitled to unemployment insurance 
92. From 1 June 2007 the basic gross benefit amount had been PLN $538.30 .^{56}$ The actual amount to be paid is determined according to the person's employment history. People with an employment record of less than 5 years are entitled to $80 \%$, and those with more than 20 years receive $120 \%$, of the basic benefit amount. The benefits are granted on a monthly basis in arrears, however if the UI benefit is paid only for a part of the month (i.e. if the payment of the benefit starts/ends in the middle of the month) then the amount of the benefit is decreased according to the number of days it concerns.

93. People over 50 years of age who have been registered as unemployed for more than 6 months may claim a pre-retirement allowance when they fulfil the eligibility criteria defined in the relevant legislation. ${ }^{57}$ Table 20 shows an overview of income support in unemployment paid between years 2001 and 2006. Before 2004, pre-retirement benefits and allowances were even granted without prior registration at a PUP and offered a relatively easy way to exit from the labour force. The legislative changes then restricted the eligibility criteria and greatly reduced the number of new grants of these types of pre-retirement income support in 2005 and 2006, although other forms of early retirement remain significant in Poland. ${ }^{58}$

Table 20. Number of unemployment and pre-retirements benefits in payment, 2001-2006

\begin{tabular}{llllllll}
\multicolumn{1}{c}{ Persons (thousands) and zlotys (PLN) } \\
\hline & & $\mathbf{2 0 0 1}$ & $\mathbf{2 0 0 2}$ & $\mathbf{2 0 0 3}$ & $\mathbf{2 0 0 4}$ & $\mathbf{2 0 0 5}$ & $\mathbf{2 0 0 6}$ \\
\cline { 2 - 8 } Unemployment insurance benefit & $*$ & 552.6 & 578.1 & 482.4 & 435.9 & 371.1 & 331.2 \\
& $* *$ & 441 & 463 & 484 & 494 & 507 & 524 \\
Pre-retirement benefit & $*$ & 287.9 & 350.7 & 321.0 & 289.1 & 251.1 & 213.3 \\
& $* *$ & 636 & 656 & 681 & 665 & 687 & 717 \\
Pre-retirement allowance & $*$ & 90.6 & 136.6 & 188.9 & 306.8 & 287.7 & 243.0 \\
& $* *$ & 1092 & 1119 & 1051 & 948 & 973 & 1010 \\
\hline
\end{tabular}

* Average number of beneficiaries in thousands.

** Average monthly gross benefit amount in zlotys (PLN).

Source: CSO (2008a); and MPiPS (2007k).

or a scholarship; for people entitled to permanent social assistance (see Section 4 below); for participants in programmes of socially useful works (see Box 1); and for overcoming homelessness.

56. Benefit amounts are adjusted on a yearly basis as of 1 June of the given year. The gross benefit amount is subject to deduction of personal income taxes and health insurance contributions, but not other social security contributions that are deducted from wages. For a comparison of net unemployment benefit with the net wage, see www.oecd.org/els/social/workincentives.

57. From the 1990s the Polish social security system has contained incentives for early withdrawal of elderly people from the labour market. A rather broad system of disability allowances was in 1997 "replaced" by the system of pre-retirement benefits and allowances, which were financed from the Labour Fund. Eligibility criteria were reformed by the Act of 30 April 2004 on pre-retirement allowances, and from August 2004 they are financed from the national budget and paid out by the ZUS (Zakład Ubezpeczień Społecznych - Social Security Institution) (MGiP, 2005).

58. There were no new entrants to pre-retirement benefit and only 5887 new entrants to pre-retirement allowance in 2006, so these forms of pre-retirement benefit are now being effectively phased out (Eurostat, 2008). However, about a million people below pension age, not shown in Table 20, are early retirees within the mandatory pension system; entry to this form of early retirement remains possible at least until 2009, when the first cohorts covered by the new pension system introduced in 1999 will reach retirement age (Chloń-Domińczak, 2007). 


\section{B. Required labour market behaviour}

\section{Availability}

94. UI beneficiaries, like all other registered unemployed, must be able and willing to work on a full-time basis, and disabled unemployed people are expected to be ready to accept a job involving at least half of the established working time. Ability and willingness to work are declared at the point of registration when the unemployed person signs a document confirming their awareness of all obligations. The unemployed may only restrict their availability for work on grounds of a health condition, and must always document this with a medical certificate. When requested by a placement officer, the person must always undertake a medical or psychological assessment for the purpose of verifying his/her capacity to work. A refusal will lead to immediate de-registration for a period of three months and loss of benefit.

95. Health restrictions and short-term sickness create problems for the PUP as they have virtually no possibility of verifying the legitimacy of medical certificates. Some PUP require that the unemployed bring medical statements on official forms that are registered by the Social Security Institution (ZUS). This practice may reduce the incidence of illegitimate incapacity-to-work statements. However, there is a further problem of poor co-operation between the two institutions and imperfect links between legislation. When a PUP asks for further verification of "strange" medical statements, the ZUS would usually refuse claiming that the unemployed do not fall under their competence.

96. Another problem results from an incomplete decentralisation of competences in terms of employment services. The PUP administrative decisions may be revoked by the respective level of state administration, either the voivode or the Ministry. Quite often the decisions issued by PUP about sanction de-registration are revoked by the Ministry. As the PUP say, the Ministry is "very tolerant to the unemployed". Such practices may undermine the authority of the PUP in relation to their clients. Moreover, it deprives them of instruments contributing to the activation of the unemployed - a task for which the PUP are in fact held accountable.

97. The unemployed must report to PUP in person on determined days to confirm their availability for work and receive information about job and/or training offers. The frequency of reporting is not defined in the law, ${ }^{59}$ but with respect to the UI beneficiaries monthly reporting is usually applied ${ }^{60}$ Other clients are required to report in person once in three months. The practice differs among individual PUP and some of them apply a three-month frequency of reporting to all clients.

98. In general, PUP focus their attention on monitoring of the behaviour of UI beneficiaries ${ }^{61}$ while the others "are just registered". "A large number of the registered does not seek any job and according to international definitions should not be counted as unemployed" (RWI, 2005). OECD (2008) too recommended "that work-availability and job-search requirements be tightened in the unemployment benefit system".

59. However, according to law, for the unemployed child alimony defaulters the dates of reporting should be determined on a ten-day basis.

60. According to the new standards of labour market services, with which the PUP must comply before 30 June 2008, the first contact after the registration shall take place within the following 7 days in case of a person entitled to the unemployment insurance benefit and within 30 days for other clients.

61. The number of people, who were subject to any form of activation, has increased by 38000 between 2005 and 2006. MPiPS $(2007 \mathrm{~m})$ does not specify whether this only concerns the unemployment insurance beneficiaries but it used this argument for explaining the drop in the spending on the unemployment insurance benefits. 
99. Table 21 shows that the percentage of the year-end stock of registered unemployed people with a UI entitlement dropped from $20 \%$ in 2001 to $13.5 \%$ in 2006. Statistics for terminations of UI claims are not available, but the average duration of spells appears to exceed six months. ${ }^{62}$ Also, in 2006 only about $13 \%$ of spells terminated with a grant of the activation allowance. ${ }^{63}$ These statistics confirm an impression that most beneficiaries exhaust their full benefit entitlement.

100. Over $30 \%$ of all de-registrations of unemployed people (including those without UI entitlement) are on grounds of non-availability for work (see Table 16 above). However most of the de-registrations concern non-beneficiary registrants. More specific statistics for terminations of UI claims would be needed to clarify whether the PES often imposes stops of benefit for reasons related to availability for work.

Table 21. Unemployment insurance coverage of registered unemployment, 2000-2007

Percentages

\begin{tabular}{ccc}
\hline & $\begin{array}{c}\text { Ul entitlements at registration } \\
\text { among all newly registered }\end{array}$ & $\begin{array}{c}\text { Ul entitlements at the end of the year } \\
\text { among all registered at the end of the year }\end{array}$ \\
\cline { 2 - 3 } $\mathbf{2 0 0 0}$ & 33.2 & 20.3 \\
$\mathbf{2 0 0 1}$ & 35.4 & 20.0 \\
$\mathbf{2 0 0 2}$ & 32.1 & 16.7 \\
$\mathbf{2 0 0 3}$ & 28.6 & 15.1 \\
$\mathbf{2 0 0 4}$ & 26.7 & 14.2 \\
$\mathbf{2 0 0 5}$ & 24.2 & 13.5 \\
$\mathbf{2 0 0 6}$ & 22.4 & 13.5 \\
$\mathbf{2 0 0 7}$ & 20.0 & 14.3 \\
\hline
\end{tabular}

Source: www.psz.praca.gov.pl, and author's calculations.

101. The new standards of labour market services issued in $2007^{64}$ do not require reporting on a more frequent basis. Placement officers shall analyse, at least once every three months, the unemployed person's registration card in terms of job offers and other proposals presented to date. When no such offers have been proposed over the period of three months, the placement officer shall within next 21 days determine a contact with the unemployed person for which case he/she shall analyse and prepare proposals of available job and/or training offers (MPiPS, 2007e).

102. When the beneficiary failed to report in person on a determined date, a justified excuse will be accepted within the following seven days. Failure to report is justified when the person documents sickness, family restrictions or any temporary crisis. Unjustified absence will lead to immediate de-registration for a period of three months and loss of benefit.

103. Current practice also varies in terms of contacting the unemployed in-between the dates determined for reporting in person. Some PUP provide information on suitable job offers and/or training exclusively when the client comes in person and do not try to notify him or her in between. Placement officers claim that, due to the high client/staff ratios (see Table 6), they only have time to apply this method of work.

62. The average duration of newly registered unemployment spells is about a year (because the stock is similar in level to the annual inflow): and in 2006 and 2007, since the share of beneficiaries in the stock of registered unemployed was about two-thirds of their share in entrants to registered unemployment (Table 21), the average duration of UI spells must also have been about two-thirds.

63. In 2006 there were a total of 666624 exits from the UI benefit and 88587 entrants to the activation allowance (Eurostat, 2008).

64. The PES should have complied with the standards before 30 June 2008. 
104. Nevertheless, some PUP reach out to their clients, mainly by serving a summons by recorded delivery. ${ }^{65}$ Contacting clients on phone or e-mail is not very popular as this type of communication can hardly be proved. In the Warsaw Labour Office, for instance, a failure to collect the summons is treated as a refusal to co-operate and leads to de-registration and loss of benefit. Hence, for their clients it is rather risky to be absent from their place of residence. When they notify the PUP in advance of their non-availability for work that will not exceed 30 days, the benefit will be reduced by that period but they will not be de-registered and will retain the remaining UI entitlement. When however they intend to be absent from their place of residence for a longer period, they would be advised to voluntarily de-register "in order to avoid problems". ${ }^{66}$ Such de-registration is not followed by any sanction, neither in terms of benefit entitlement nor with respect to re-registration at any time.

\section{Suitable work}

105. The unemployed must accept suitable employment or other paid work offered by a PUP. When they refuse they are de-registered and lose UI entitlement. The unemployed must accept suitable employment or other paid work offered by a PUP. When they refuse they are deregistered for a period of 90 days. After re-registration they may restore their UI entitlement provided that they fulfil the required contribution conditions. Refusal to take up a job under the intervention works or public works programmes, or to undertake work experience or participate in training or vocational preparation at a workplace, is treated as non-availability for work.

106. According to law the unemployed are required to be available for full-time jobs, i.e. up to 40 hours per week. ${ }^{67}$ Yet, some PUP apply a less strict approach and, subject to individual consideration, would not require for instance a lone parent with caring responsibilities to be available on a full-time basis. Other PUP never accept such restrictions and treat them as non-availability for work. ${ }^{68}$ The person concerned may be offered a part-time job if available but PUP would normally not wait until such a job offer arrives. On the other hand, PUP may grant a child-care allowance to an unemployed lone parent with a child below 7 years of age when he or she takes up work or participates in any of the active labour market programmes. Similar allowance may be granted for care of other dependants.

107. The legislation does not mention any delay before taking up work. Usually, the employer specifies the date of take-up in the job offer. Potential delays requested by the unemployed person are always subject to his/her agreement with the employer. When referred by a placement officer the unemployed person should normally undertake the job interview within seven days and report on its result on a date determined by the placement officer.

108. The unemployed may normally not refuse a suitable job offer claiming that they are awaiting start of another, possibly more favourable, job. However, here again, the approach differs among individual PUP. Some would treat each case individually and possibly tolerate a delay on these grounds. Other PUP do not tolerate it at all and would rather advise the person to voluntarily de-register.

65. The postman must try and reach the person at home twice, afterwards the delivery (even if failed) is considered accomplished. PUP therefore leave two weeks for delivery and determine the date of personal contact only after that period.

66. The unemployed people willing to travel to another region for job-search purposes have no possibility of reporting to a PUP in the place of their temporary stay. Thus, they either risk they will not be reached by a summons or prefer voluntary de-registration for the time of travel.

67. The disabled unemployed are required to be available for jobs involving at least half of the established working time.

68. The unemployed may never restrict their availability across the week and refuse, for instance, work on weekends. 
109. Socially maladjusted individuals are often not entitled to the UI benefit as they rarely have the required employment record. ${ }^{69}$ Even though many of them apparently avoid work, failure of the activity test is only proved when they refuse a suitable job offer or a referral to a job interview, or fail to attend the interview. Otherwise, a PUP has no grounds for deciding on de-registration.

110. Problematic individuals often intentionally behave so as to discourage employers from offering jobs. But as long as they have not been offered a job, a PUP has no instrument for proving non-availability for work. According to some PUP, with respect to people entitled to the shortest benefit period (six months) it is rather difficult to state they avoid co-operation.

111. In general, any employment or other paid work subject to social insurance can be a suitable job. Job offers must comply with the legislation on working conditions. PUP may notify a labour inspectorate of alleged employer's misconduct but the process of documentation usually takes too long and provides the employer with sufficient time for improvements. Unless the malpractice is confirmed by the court, job offers notified by the employer may not be refused. Some PUP however run unofficial blacklists of problematic employers, and inform candidates for work about the employer's past behaviour.

112. Some PUP tolerate restrictions on long or inconvenient working hours on grounds of care responsibilities or other reasons but every case is considered individually. By contrast, in the Warsaw Labour Office no such restrictions are taken into account and the unemployed must prove full availability for any suitable work including part time. In terms of casual work, employers do not usually state in advance that they want to hire workers for a very short period.

113. The time of commuting by public transport shall not exceed three hours (MPiPS, 2004a). When the commuting time falls within this limit the job may not be refused on grounds of travel-to-work costs. The unemployed who accept longer commuting hours may be granted an allowance for covering the costs of commuting. Relocation for work may not be requested but again, PUP may refund the accommodation costs of a person who took up a job or participates in an active labour market programme outside his or her place of residence. In 2008, when the integrated national database of job offers was still under construction, the PUP did not offer jobs from other regions as they had no access to databases of other PUP.

114. Jobs for which the person concerned has sufficient qualifications or vocational experience, and which are compatible with his/her health condition, are considered suitable. A job is also deemed suitable when the person may acquire the requested qualifications through training provided by a PUP. In that case he or she may not refuse the training or the job. The level of educational attainment is not mentioned in law under the suitable work criteria, but in the initial period placement officers would normally not ask the unemployed to accept jobs involving lower-than-attained level of education. The criteria may be relaxed later in the unemployment spell, but at the PUP interviewed for this report where the benefit period lasted only six months this question was irrelevant.

115. In terms of wage level, every job complying with the legislation on the minimum wage is deemed suitable and cannot be refused..$^{70}$ On the other hand, the beneficiaries who accept a part-time job offered by the PUP that involves actual remuneration below the minimum wage may be granted the activation allowance. The activation allowance may also be granted when the beneficiary takes up work based on individual job search. In 2005, the activation allowances were granted to 105900 beneficiaries who started

69. However, entitled beneficiaries who are undergoing alcoholism or drug treatment, and thus are not available for work or for participation in an active labour market programme, retain their benefit during the entitlement period.

70. Restrictions in terms of work expenses are considered individually by some PUP while others do not accept any restrictions in this respect. 
working from own initiative and 3500 benefit recipients received the allowance because they accepted a part-time job offered by the PUP. In 2006, the numbers significantly dropped, to 88200 and 355 people, respectively. The drop was mainly caused by a reduced interest of the unemployed in accepting work during UI benefit spell and the reduced amount of the activation allowance (MPiPS, 2007m).

116. Although the Polish legislation generally requires that UI beneficiaries, as well as all registered unemployed, be available for work and undertake individual job-search activities, it fails define clear requirements in this respect. Individual PUP were in fact free to decide about the intensity of contacts, number of required job-search activities or criteria for assessing suitable work. The regulation on standards of labour market services adopted in 2007 tries to address the problem of inconsistency in the approaches applied by individual PUP. A unified set of standards related to all main PES functions including placement services was introduced. However, the regulation failed to tighten the requirements vis-à-vis the unemployed. It seems that PUP usually do apply quite strict monitoring of UI beneficiaries, but intensive activation requirements should also be extended to people whose UI entitlement expired, especially the long-term unemployed who are very often recipients of social-safety-net benefits.

117. Delivery of intensive activation services is only possible with adequate levels of staffing. In a situation where the costs of staffing are covered from the self-government budgets, the level of staffing is fully dependent on political decisions at a local level. Although the Ministry defined in 2007 the minimum numbers of main function staff to be employed by PES institutions, the actual implementation of this requirement might be difficult due to budget constraints at a local level.

\section{Approaches to the activation of beneficiaries of social-safety-net benefits}

\section{A. Benefit administration}

118. Social assistance in Poland is organised and delivered both by the central government and the self-government structures, with quite extensive decentralisation of tasks to the self-governments. Both sectors should deliver the tasks in a close co-operation, based on a partnership principle, with NGOs, churches and other actors active in this field (MPiPS, 2004b). The social assistance system shall deliver two missions: helping individuals and families overcome difficult life situations and achieve self-sufficiency and social integration; and providing them with basic living conditions that conform to human dignity. According to law, active engagement and co-operation in this respect is required from the beneficiaries.

119. The central government manages its areas of responsibility through the Minister of Labour and Social Policy and the 16 voivodes. Within the legal framework of the Act of 12 March 2004 on Social Assistance (MPiPS, 2004b), the Minister designs policies and programmes determining overall directions and priorities, which are described in the National Strategy of Social Inclusion. The government programmes are implemented by the voivodes or further delegated to the self-government bodies (voivodeships, poviats and gminas).

120. Given the extensive decentralisation of the system, the central government tries to regulate the provision of social services. To this end the Minister issued in 2007 delivery standards, adherence to which should be controlled by the voivodes. According to law, the voivodes shall supervise all tasks realised by the self-government bodies and control the quality of services delivered by external non-public providers. In 2007 voivode offices undertook 1529 controls of the 6900 social assistance institutions (including both social assistance centres and other institutions) under its responsibility. However, in interviews social workers reported that voivodeship surveillance consists only of receiving annual reports from the social assistance centres. 
121. Substantive social assistance is delivered by the self-government structures. The poviats carry out tasks devolved by the central government as well as those for which they are directly responsible. The devolved competences include providing integration assistance to refugees and people with mental disorders, for which they receive funds from the state budget. In the framework of their direct competences they run poviat family support centres and sheltered housing, and deliver tasks in the area of foster care and other types of substitute family care (MPiPS, 2004a).

122. Income support and the activation of employable people are delivered at a gmina level. Each gmina has social assistance centres (ośrodek pomocy spolecznej - OPS) which are organisational units of the gmina self-government offices. They administer and pay out social assistance cash benefits, undertake initiatives aimed at a social and employment activation of beneficiaries, provide basic living conditions and deliver social work and related activities. Among other institutions delivering some form of social assistance are regional social assistance centres and poviat centres for helping families (which voivodships and poviats are obliged to establish) as well as social assistance houses, centres for specialised counselling, centres for care and education, centres for crisis intervention and support centres, some of these institutions having further sub-categories (MPiPS, 2007g).

123. According to law, gminas and poviats should develop their own strategies, which define preventive and curative measures with respect to the risk groups in their territories, for solving social problems. They are quite independent in targeting initiatives and selecting measures according to local needs. However, local authorities fail to benefit from their substantial independence in designing policies. The strategies are rarely based on sound analyses and a proper system of monitoring and evaluation is often missing (Wóycicka, 2006).

124. Co-operation between the OPS and the public employment service, which is crucial for the successful activation of social assistance beneficiaries, is rather weak. The non-functioning of this alliance is perceived as a problem more by social workers than the PUP staff. Improved collaboration between the two institutions was expected to result from new legislation adopted in 2004 both in the area of PES and social assistance, but in fact "the regulations have pure bureaucratic character and they lack real incentive to mobilise the institutions for better co-operation" (Wóycicka, 2006).

125. In 2006 there were 2495 gmina social assistance centres which employed 41484 staff. The majority of the OPS are small with less than 10 staff, but more than 100 OPS have over 50 staff (Table 22). The structure of staff is decided by individual gminas, but it must follow the centrally-determined proportion of at least 1 social worker for each 2000 inhabitants. ${ }^{71}$ In any case every gmina must employ at least three social workers. Interviews at the OPS disclosed that gminas have difficulties in complying with these requirements, and often fail to employ the required staff levels due to local budget constraints. A typical structure of staff in the OPS includes social workers, psychologists, and specialists for family issues, benefit administrators and other administrative staff. A more detailed breakdown of functions is presented in Table 23.

Table 22. Social assistance centres by number of staff, 2006

\begin{tabular}{cccc}
\multicolumn{2}{c}{ Units } \\
\hline $\begin{array}{c}\text { Total number of gmina } \\
\text { social assistance centres }\end{array}$ & Less than $\mathbf{1 0}$ staff & $\mathbf{1 0 - 5 0}$ staff & Mocial assistance centres with \\
\hline 2495 & 1540 & 833 & 122 \\
\hline
\end{tabular}

Source: MPiPS (2008b).

71. It might be argued that relating the required staffing to the number of inhabitants, rather than to the number of social assistance beneficiaries, fails to reflect the actual pattern of needs in individual gminas. 
DELSA/ELSA/WD/SEM(2009)8

Table 23. Structure of staff in social assistance centres, 2006

Units and percentages

\begin{tabular}{|c|c|c|c|}
\hline \multicolumn{2}{|r|}{ Function } & Staff & Percentage of total stafi \\
\hline \multicolumn{2}{|l|}{ Total } & 41484 & 100.0 \\
\hline \multicolumn{2}{|c|}{ Directors } & 2538 & 6.1 \\
\hline \multicolumn{2}{|c|}{ Deputy directors } & 371 & 0.9 \\
\hline \multicolumn{2}{|c|}{ Social workers - Total } & 15767 & 38.0 \\
\hline \multirow{5}{*}{ Of which } & Senior social work specialist & 511 & 1.2 \\
\hline & Social work specialist & 3128 & 7.5 \\
\hline & Senior social worker & 7064 & 17.0 \\
\hline & Social worker & 5062 & 12.2 \\
\hline & Chief specialist - Social worker & 2 & 0.0 \\
\hline \multicolumn{2}{|c|}{ Other chief specialists } & 41 & 0.1 \\
\hline \multicolumn{2}{|c|}{ Candidates of social work } & 663 & 1.6 \\
\hline \multicolumn{2}{|c|}{ Tutorial service staff } & 6202 & 15.0 \\
\hline \multicolumn{2}{|c|}{ Special tutorial service staff } & 958 & 2.3 \\
\hline \multicolumn{2}{|c|}{ Consultants } & 359 & 0.9 \\
\hline \multicolumn{2}{|c|}{ Coordinator for ICTs } & 204 & 0.5 \\
\hline \multicolumn{2}{|c|}{ Legal advisor } & 240 & 0.6 \\
\hline \multicolumn{2}{|c|}{ Other staff } & 14141 & 34.1 \\
\hline
\end{tabular}

Source: MPiPS (2007g); and author's calculations.

126. In 2006 temporary benefits (the main type of benefit paid in cases of unemployment, see below) were granted to 645012 people in 628681 families which had 2062574 members in total. Altogether 511285 people, in 497784 families with 1621106 members in total, were granted social assistance (usually temporary benefit, but in some cases another form of social assistance) on grounds of unemployment.

127. On average 41 people were granted temporary benefit for each social worker - a ratio at first sight much more favourable than in the PUP, where each placement officer has 1132 unemployed clients on average (see Table 6). However, various differences in the significance of the figures should be kept in mind:

- The figure for unemployed clients per placement officer refers to a stock of 2.309 million unemployed clients, of whom only about one-seventh were receiving a UI payment (see Table 6 and Table 20);

- Since temporary benefit is granted for short periods, the stock of people supported by it at a particular point in time is probably smaller than the total annual number of grants $(645012)$ cited above;

- In relevant cases, social workers conduct regular inquiries of the family environment (at least once in every six months, but often on a more frequent basis), and this involves much more time per person than placement work; and

- Social workers do not deal only with temporary benefit or employable clients. Social work services of some kind, in the area of the direct competences of the gmina, were delivered in 2006 to 1481051 families with 4756328 members and 2452943 main recipients. On this basis social workers dealt on average with 156 main recipients and altogether with 302 persons in families. 


\section{B. Eligibility criteria}

128. Social assistance benefits are granted when the family income does not exceed a determined threshold ${ }^{72}$ and, at the same time, the family members find themselves in any of the following situations: unemployment, disability, orphanage, homelessness, family violence, integration difficulties after the release from a penal institution or other type of institutional care, drug and/or alcohol addiction, and extraordinary situations such as natural disasters, etc (MPiPS, 2004b). Different types of benefits are granted according to the character and scope of the problem.

129. People who are completely incapable of work due to age and/or disability are entitled to a permanent benefit (zasilek staly). A targeted lump-sum benefit (zasitek celowy) may be granted in cases of unexpected difficulties or misfortune, in some specific situations without a family income test. More often it is granted to people with no income for the purpose of purchasing necessary food, medicines and treatment, clothing, daily necessities and for covering expenses on health benefits (MPiPS, 2004b). These benefits have a pure income protection role and do not require activity from their recipients.

130. The remaining types of social assistance benefits are in principle targeted at families with employable members. ${ }^{73}$ The temporary benefit (zasilek okresowy) is usually granted on grounds of a long-term disease, disability and/or unemployment, and when it can help maintain or acquire entitlement to the benefits from other social security schemes (MPiPS, 2004b). Benefit amounts are determined in law as the difference between the established income threshold and the actual income of the family. One part of the benefit is guaranteed by national legislation and the other is optional depending on gmina policy.

131. In 2004 the system went through major changes that simplified the eligibility criteria for the cash benefits and reduced their diversity. "The reform reduced the discretional way of establishing the level of allowances $^{74}$ for social assistance beneficiaries, which often had led to minimising these allowances as a result of lack of social assistance financial sustainability." (Wóycicka, 2006). In the old system gminas might have refused income support for a family on grounds of lack of resources. This, as well as the low level of the minimum guaranteed benefit, can explain why the average grant per temporary beneficiary was less than PLN 500 in 2004 (Table 24), a small fraction of the average grant made to those on the permanent benefits or the social pension. From 2004, the temporary benefit may be claimed upon fulfilling the conditions stipulated in law. Mandatory temporary benefits were introduced at a rate of $20 \%$ of the income gap in 2004, scheduled to increase progressively to reach $50 \%$ in 2009 . The central government introduced subsidies to self-governments from the state budget for financing the guaranteed part of temporary benefits: the average amount paid has increased, but remains very low. ${ }^{75}$ Total expenditure on temporary benefit in 2006 was well below expenditure on PES and administration functions (see Table 13) and less than a third of expenditure on UI benefits, despite the smaller caseload for UI benefits (see Table 20).

72. As of January 2006 the income threshold of an individual living alone is PLN 477, and for a person living in a family it is PLN 351. For the purpose of granting temporary or targeted benefits individual gmina councils may increase these amounts by way of resolutions.

73. The claimants must always first apply for the unemployment insurance benefit at a PUP.

74. In this report the Polish word "zasiłek" is translated as "benefit", but in other literature it is sometimes translated as "allowance".

75. In case of large families, however, the actual amount paid may nevertheless become quite high in relation to the minimum wage. 
Table 24. Types of social assistance benefits granted, 2000-2006

Thousands of persons and millions of zlotys (PLN)

\begin{tabular}{|c|c|c|c|c|c|c|c|c|}
\hline Type of benefit & & 2000 & 2001 & 2002 & 2003 & 2004 & 2005 & 2006 \\
\hline \multirow{2}{*}{ Total (including Social pension) } & * & 2144 & 2149 & 2549 & 2640 & 2649 & 2813 & 3052 \\
\hline & ** & 3107 & 3297 & 3854 & 3726 & 3939 & 4254 & 5161 \\
\hline \multirow{2}{*}{ Total (excluding Social pension) } & * & 1965 & 1943 & 2318 & 2388 & 2410 & 2575 & 2816 \\
\hline & ** & 2415 & 2432 & 2849 & 2880 & 2571 & 2886 & 3737 \\
\hline \multirow{3}{*}{$\begin{array}{l}\text { Monetary (excluding } \\
\text { Social pension and other) } \\
\text { Of which: }\end{array}$} & * & 1603 & 1388 & 1696 & 1665 &.. &.. & \\
\hline & ** & 1222 & 1142 & 1419 & 1401 & 1226 & 1623 & 2370 \\
\hline & & & & & & & & \\
\hline \multirow{2}{*}{ Permanent benefit ${ }^{a}$} & * & 69 & 71 & 74 & 70 & 162 & 171 & 182 \\
\hline & ** & 228 & 283 & 293 & 291 & 471 & 517 & 561 \\
\hline \multirow{2}{*}{ Permanent compensatory ${ }^{a}$} & * & 83 & 100 & 116 & 140 & - & - & - \\
\hline & ** & 217 & 280 & 350 & 413 & - & - & - \\
\hline \multirow{2}{*}{ Temporary benefit } & * & 556 & 268 & 470 & 348 & 552 & 669 & 645 \\
\hline & ** & 426 & 180 & 310 & 197 & 254 & 543 & 612 \\
\hline \multirow{2}{*}{ Targeted benefit } & * & 895 & 949 & 1036 & 1107 & 1068 & 1271 & 1701 \\
\hline & ** & 351 & 399 & 466 & 500 & 501 & 563 & 1197 \\
\hline \multirow{2}{*}{ Social pension ${ }^{b}$} & * & 179 & 206 & 231 & 252 & 239 & 238 & 236 \\
\hline & ** & 692 & 865 & 1005 & $846^{c}$ & 1368 & 1368 & 1424 \\
\hline \multirow[t]{2}{*}{ Other monetary assistance ${ }^{d}$} & * & .. & .. &.. &.. &.. & .. & \\
\hline & ** & 579 & 656 & 696 & 697 & 530 & 554 & 583 \\
\hline \multirow[t]{2}{*}{ Non-monetary assistance ${ }^{e}$} & * & 1080 & 1084 & 1324 & 1398 & 1182 & 1292 & 1329 \\
\hline & ** & 614 & 634 & 734 & 782 & 815 & 709 & 784 \\
\hline
\end{tabular}

Data not available.

- Not applicable.

* Beneficiaries in thousands. Beneficiaries may be counted several times under individual types of benefit. For social pension the number reported is the annual average of monthly stock figures (i.e. each statistical beneficiary represent 12 monthly payments). The definitional basis of figures for other categories is not stated and data should be treated with caution. For targeted benefit, which is paid as a lump-sum, data would probably refer to the number of payments made.

** Benefit expenditure.

a) Prior to 2004, permanent benefit was payable to a person caring for a child requiring constant care or nursing, and permanent compensatory benefit (zasiłek stały wyrównawczy) was payable to people who were themselves entirely unable to work. As from 2004 only the permanent benefit, targeted similarly to the previous permanent compensatory benefit, exists.

b) Social pension was included in the totals for social assistance benefits published in the Statistical Yearbook until 30 September 2003, and not thereafter.

c) Data cover the period 1 January to 30 September.

d) Other monetary assistance calculated as the residual after subtracting non-monetary assistance and itemised components of monetary assistance. This calculation is not valid for beneficiary numbers which are not additive, i.e. a person who is counted as a beneficiary of two or more benefits is counted only once in the totals.

e) Non-monetary assistance includes Maternity care, Shelter, Meals, Clothing, Treatment costs and assistance in the form of services. Source: CSO, Concise Statistical Yearbook, 2002 and later issues in the same series, tables on social assistance benefits and Social pension; and author's calculations.

132. In 2006 and 2007 the guaranteed benefit amount represented $25 \%$ of the income gap for an individual living in a single-person household and 35\% for a person living in a family ${ }^{76}$ Minimum benefit levels determined in law may be increased by way of a resolution of a gmina council in which case the top-up amount is covered from the particular self-government budget. ${ }^{77}$ According to Wóycicka (2005) gminas in general are not

76. From 2008, minimum guaranteed benefit level is $50 \%$ of that difference.

77. Gminas may also grant other types of support aimed at improving the client's financial self-sufficiency. The in-cash assistance includes interest-free loans and special targeted lump-sum benefits provided from the local budget. The in-kind form of help consists in lending the equipment for the client's self-employment activities. These benefits are subject to an activity test and any failure to undertake employment or other form of activation may lead to benefit cuts or benefit stops. While the temporary benefit is claimable upon fulfilling the conditions determined in law, granting the support aimed at improving the client's financial self-sufficiency is exclusively subject to a gmina decision and cannot be claimed as a right. In particularly justified cases, the gminas may also grant financial assistance to families 
enthusiastic about investing their own funds in financial assistance to the poor. In a survey of several communities, conducted in 2005 , only one of them was increasing the amount of temporary benefit to $50 \%$ of the income gap. Benefit duration is always determined at a gmina level by a social worker according to individual circumstances. A common practice among OPS social workers is to grant the benefits for three months, then verify the entitlements and, if circumstances remain, grant the benefit for another three months.

\section{C. $\quad$ Activation measures}

133. Although the temporary benefit is in principle targeted at employable people, its actual conditionality upon the beneficiary's activation depends on the approaches applied by individual gminas. Although, according to law social workers may cut or stop the benefit due to insufficient co-operation on the side of the beneficiary, in fact they rarely do so. They would usually try to grant income support on other grounds listed in the legislation, ${ }^{78}$ especially with respect to families with children. In fact, the legislation itself requires that when considering reduction or stop of benefits the situation of people dependent on the main beneficiary shall be taken into special consideration (MPiPS, 2004b). Anyway, social workers have been somewhat discouraged from deciding on benefit cuts because often their decisions were overturned by gmina appeal institutions.

134. The Act on Social Assistance introduced, in 2004, social contracts between a social worker and a beneficiary. Social contracts are counterparts to the individual action plans used by public employment service. They are written documents specifying mutually agreed tasks that should help clients overcome difficult life situations. However, the application of social contracts is at the discretion of individual social workers. $^{79}$ From 4079638 people who benefited from one of the forms of social assistance in 2006 (i.e. social assistance benefits and/or gmina social work services), only $2 \%$ had concluded a social contract. ${ }^{80}$

135. Typical OPS clients are individuals or families whose main problem is not the failure to find work. They often have other deep-rooted problems such as alcoholism, homelessness or family violence that prevent effective job search. Social workers therefore first concentrate on helping them mitigate or overcome these problems, by referring people to therapies and delivering other forms of social work with respect to the whole family. This social activation is considered a priority mission and would always precede activation for work. It may take from 2 to 12 months depending on individual circumstances and scale of the problem.

136. When social activation has brought some results, social workers would start initiatives in terms of helping the people enter in the labour market, and for this several pathways are available. First, they may refer their clients to register with a PUP as unemployed people or jobseekers so that they may benefit from the labour market services offered by labour offices. The problem is that PUP mainly focus their attention on the unemployed who are entitled to UI benefits and not the long-term unemployed recipients of social assistance. When referring people to active labour programmes, PUP would often give preference to "their" clients rather than engaging the people referred by social workers. ${ }^{81}$ The OPS are thus often thrown

whose income exceeds the income threshold. In these cases the financial assistance must be repaid. The assistance may take the form of targeted (lump-sum) benefit, the temporary benefit or assistance in kind.

78. According to interviewed social workers, they can usually find another official reason for granting the benefit.

79. The conclusion of social contracts is only mandatory for clients of the so-called social integration centres (CIS) and social integration clubs (KIS).

80. The data on social contracts have a survey character and cover the early period of their implementation.

81. Interviews with PUP staff confirmed certain disenchantment with the practice of referring social assistance clients to register with PUP. According to the PUP, these clients are often discouraged, face multiple disadvantages and inapt to undertake any work. Some PUP believe that social assistance centres are only shifting their responsibilities to the PUP, and/or are inviting their clients to register as unemployed just to have their health contributions paid. 
back on their own resources and must mobilise these in order to provide for training or other activities needed in the process of the labour market activation of their clients.

137. Social workers, too, confirmed that even when their clients register as unemployed they would often attend personal contacts at a PUP only in order to sign the attendance list that entitles them to have the contributions for health insurance paid by a PUP. This statement supports the idea that the work-availability and job-search requirements are not strictly enforced with respect to the long-term unemployed, at least by some PUP. On the other hand, the fact that the PUP have limited possibilities of proving non-availability for work of problematic clients discourages them from engaging in their activation on a larger scale. Moreover, according to social workers many of their clients would refuse registration at a PUP even at the cost of losing access to public health insurance.

138. The integration of social work with the main activities of the PUP is deficient. Most OPS have no computer interface with their respective PUP and thus cannot be immediately notified of the beneficiary's de-registration from the unemployment registry or other relevant events. ${ }^{82}$ When referred to register with a PUP the social workers usually require the beneficiaries to bring a confirmation of their reporting at a labour office. One interviewed OPS in Warsaw requires that their clients bring such confirmation in person on a monthly basis. When they fail to do so, social workers ask the PUP for information in writing, which can be a ponderous process as it is not exceptional for the PUP to take up to two months to respond. Verification on the phone depends on the quality of personal contacts between the two institutions. The same applies to information flows in general. When personal contacts are good, social workers may even be notified about recruitments for jobs that might be suitable for the social assistance clients, but it seems that this approach is rather exceptional. There is no standard procedure in this respect.

139. The fact that collaboration between the OPS and the PUP is weak is all the more disturbing because the majority of unemployed people receive income support from the social assistance system. In 2004 almost $85 \%$ of people receiving temporary benefit were unemployed, and the unemployment of the main recipient was the grounds for receiving one of the forms of social assistance in $53 \%$ of all cases. However, out of 100 clients of the PUP, in fact 2 need no job-search assistance, 18 will find work as a result of participation in a standard active labour market programme, and the remaining 80 individuals require long-term assistance that might not result in undertaking a full-time job for an indefinite period (MPiPS, 2007a). This group should constitute the joint clientele of the PUP and the social assistance centres.

140. Although almost $100 \%$ of the PUP declares that they collaborate with the gmina OPS, less than half of the forms of collaboration implemented represented real work with the hard-to-employ groups. The forms of co-operation are largely limited to informing the other party about their programmes (in 64\% of cases). Joint initiatives such as operating social integration centres (CIS) or social integration clubs (KIS) were reported by $27.5 \%$ of PUP and joint realisation of ESF projects by $17 \%$ of them. Coordination between the two institutions in terms of designing local policies is poor (MPiPS, 2007a).

82. Work on the integration of IT systems between PUP and social assistance centres is already under way within the framework of the SYRIUSZ project, which should integrate the systems of all public labour market and social welfare institutions. This work should be completed before end 2008 (MPiPS, 2007j). In June 2008, however, there was still no central application in place that would enable data exchange between social assistance centres and PUP, and it was not clear that this would be achieved according to the planned schedule. The delay might have been caused by uncertainties in the interpretation of data protection legislation. However, there cases where a computer interface between PUP and social assistance centres has been established based on an initiative of the poviat self-government. Some poviats in the Slaskie Voivodeship (e.g. the City of Semianovcie Slaskie), where the local initiative was supported by the Ministry, are a good example (Source: interview with MPiPS staff). 
141. In order to provide their clients with job-search assistance and counselling on labour market issues, the OPS often run job clubs that are integral parts of their organisational structure and are sometimes established and operated in association with PUP. In Warsaw, ${ }^{83}$ for instance, at the beginning of 2008 there were altogether 22 job clubs of which 18 were operated by the OPS. ${ }^{84,85}$ Social workers refer their clients to job clubs where they are advised on and trained in job-search strategies and CV preparation. The counsellors may prepare with them action plans but these are not obligatory.

142. The frequency of reporting at job clubs or the OPS is not determined in law and largely depends on the client's interest and the practice applied by individual OPS. ${ }^{86}$ According to interviewed social workers motivated clients would even drop in every day. The problematic ones are usually required to bring a certified summary of their activities undertaken in the job club. Since they often belong to the same institution, the interface between OPS and job clubs is usually smooth and social workers may easily check the behaviour and other information about their clients.

143. Similarly, OPS have no general guideline on the frequency of intensive interviews to be held with the beneficiaries. The first intensive interview is normally held before the benefit is granted and serves for the overall diagnosis of the client and his family's situation. Afterwards, the frequency of interviews is proportionate to the client's motivation, with the most determined ones even requesting an interview on their own initiative. Practices vary among individual gminas, and some OPS undertake intensive interviews together with regular checking of benefit eligibility, i.e. once in three months on average. In case of problematic clients, they may investigate through home visits.

144. The OPS can and actually do refer their clients to apply for job offers. Although according to law gminas shall co-operate with PUP in terms of disseminating job offers, social workers do not exclusively rely on this source of information. Actually, they do not have access to the internal PUP database of job offers and can only use the information advertised on the PUP public website. Social workers and job clubs mainly obtain job offers from private agencies and often they directly contact local employers. If there is no suitable job offer, the clients are asked to undertake individual job search: there is no general rule about the number of job-search activities to be reported by the beneficiary.

145. Social assistance beneficiaries who are registered as unemployed may participate in programmes of socially useful works (described in Box 1 above), which are organised by gminas and are exclusively targeted at unemployed clients of the OPS who are not entitled to UI benefit. Although a refusal to participate in the programme may lead to de-registration from the PUP, it has no legal consequence in terms of social assistance. The client will lose the status of an unemployed person but his/her health insurance contributions will continue to be paid by the OPS. It is not exceptional that all employable family members participate in the programme. However there is no sanction in terms of benefit cuts or benefit stops if other family members do not participate.

83. The Warsaw case is exceptional as the network of job clubs was established under the initiative of a PUP. In 2007, 741 people participated in the active job-search workshops organised by the Warsaw job clubs, 2248 people participated in the activation classes (zajęcia aktiwyzacyjne) and 7733 clients were provided individual counselling. The job-club databases and information were used by 79018 people (WAW, 2007).

84. Job clubs may also be established and operated by non-governmental organisations.

85. Job clubs established at OPS are not reserved exclusively to social assistance clients but are open to all public.

86. The interviews with social workers showed different approaches applied by individual social assistance centres. While some centres require reporting on job-search activities once in a month on average, the others would check the client's job-search activities once in three months, when they come for a regular confirmation of circumstances relevant for the benefit entitlement. 
146. In general, social workers in Poland have a rather high level of discretion in terms of managing the form and intensity of assistance to their clients. At the same time it is up to them to take the initiative and, acting as case managers, mobilise all available sources and local partners in ensuring necessary activities for the benefit of their clients. Many co-operate with non-governmental organisations and apply for financial resources from the ESF.

147. Although eligibility for the temporary benefit is not in general conditional on participation in activation measures, and depends on the practices applied by individual gminas, the beneficiaries referred to the so-called Social Integration Centres (CIS) are required to prove high levels of commitment to co-operate in return for receiving income support at the level of the UI benefit (Box 4).

148. Gminas and public-benefit organisation may also establish Social Integration Clubs (KIS). In 2005 there were 100 KIS in operation and in 2006 their number increased to 250 . The KIS provide counselling on legal issues, undertake self-help activities in terms of employment, housing or social welfare and provide temporary employment programmes or organise public works (see Box 1 above for a description of public works). KIS participants do not receive any integration allowance.

\section{Box 4. Social Integration Centres}

People facing serious reintegration problems may be referred to the so-called Social Integration Centres (CIS) that operate under the principles of social employment. CIS are established by the poviat or gmina self-governments or by public-benefit institutions. ${ }^{87}$ The CIS status is approved by a voivode who should ask for a marszałek's opinion. Following enabling legislation in 2004, there were $36 \mathrm{CIS}$ in operation in 2006 and 55 by end 2007. Less than 1000 people participated in CIS classes in 2005 and 2500 in 2007: the number was expected to reach 7500 to 10000 in 2008-2010.

The CIS mission consists in providing intensive guidance leading to the social and occupational reintegration of their clients. For that purpose the clients are trained in fulfilling basic social roles, managing their income in a rational way and satisfying their needs in a self-sufficient manner. In terms of the occupational reintegration they are provided necessary training along with undertaking work in the CIS workshops. The CIS may undertake activities in terms of manufacturing, trade or services while these are not subject to the legislation on economic activities. ${ }^{88}$

CIS activities are financed from gmina subventions that come from the levied tax on alcohol and the revenues from the CIS own activities. The CIS established by public-benefit organisations may receive funds from their mother institutions that come from assemblies or donations or other sources. They may also receive additional resources from the gmina budgets, the Labour Fund or the PFRON (National Fund for the Rehabilitation of Disabled Persons). Table 25 shows the structure of revenues of five CIS that were monitored in 2005.

CIS staff usually consists of a director, the administrative staff, staff responsible for the activities of social and occupational reintegration, social workers, vocational instructors, and people who have successfully completed the CIS programme and were afterwards employed in the $\mathrm{CIS} .{ }^{89}$ Front-line staff may only deal with maximum five participants. This does not apply to workers who previously were CIS clients.

87. Public-benefit institutions are non-governmental institutions acting in accordance with the Act of 24 April 2003 on public-benefit activities and voluntary work. According to this Act, public-benefit activities are socially useful activities performed by non-governmental organisations in the area of public tasks specified in that act.

88. The following activities may not be undertaken by the CIS: manufacturing of and trade in the products of the fuel, tobacco, liquor, wine and beer industries and other alcoholic products containing more than $0.5 \%$ of alcohol, and products of noble metals or containing those metals (MPiPS, 2003).

89. At the end of 2004, the CIS employed 11 to 14 staff on average (MPS, 2005). 


\section{Box 4. Social Integration Centres (Cont.)}

CIS may admit homeless people undertaking an individual programme of overcoming the homelessness, people addicted to alcohol after completing the programme of psychotherapy in a therapeutic centre, people addicted to narcotics after completing the programme of therapy in a health-care centre, people with mental disorders, unemployed people who are out of work for more than 36 months, people released from prison institutions facing integration problems, and immigrants undertaking an individual programme of integration. ${ }^{90}$ At the same time CIS participants may not be entitled to the UI benefit, early-retirement or old-age pension, a pension on grounds of incapacity to work, social pension or structural pension (MPiPS, 2003).

CIS only deal with people who are, upon undertaking intensive treatment, considered employable. They may be referred to CIS by social assistance centres, PUP, treatment institutions such as addiction treatment centres or other institutions dealing with socially-excluded people. Participation in the CIS is voluntary. Before admitting a person, the $\mathrm{CIS}$ always seeks advice from the relevant social assistance centre, which undertakes social investigation of the person's family and home situation.

Each person admitted to CIS must sign an individual programme of social employment (the programme), which is also subject to approval of the social assistance centre. The programme is developed by a CIS social worker and specifies the scope and form of the clients' social and occupational reintegration and names people responsible for the delivery of that programme. When drafting the programme individual CIS apply different approaches. In some, the programmes are prepared in close co-operation with the participant $(42 \%) .{ }^{91}$ There are CIS where the participants receive the programmes already prepared by social workers and are only asked if they agree (45\%). Some CIS, however, did not even require the participants consent $(9 \%)$.

In case of persistent breach of the programme rules and repeated absence from CIS activities, the programmes are suspended and the clients are excluded from the CIS. In 2005, for instance, the five monitored CIS had an average participant turnover of $19 \%$ and the most frequent reasons for exit were sanctions for breaching internal rules $(60 \%$ of all exits) and the participant's voluntary resignation (33\%). $10 \%$ of exits were due to entering employment or education (MPS, 2005).

The treatment in CIS is quite intensive. Normally the clients would be in CIS for 12 months, and attendance is required a minimum of six hours daily. During that period the participants receive an integration allowance ${ }^{92}$ at the level of the UI benefit. The participants start with a one-month probation period and after its successful completion they qualify for the CIS activities which may last up to 11 months with a possible extension by a further 6 months. The integration allowance is reduced by $1 / 20$ for each unjustified absence from the CIS activities. More than three unjustified absences in a month lead to the complete suspension of the monthly allowance. Conversely, for an active attitude and progress in activation, participants may be granted a motivation bonus not exceeding $20 \%$ of the integration allowance.

90. In the period between October 2004 and February 2005 the structure of clients in five monitored CIS was the following: long-term unemployed (2/3), homeless (1/5), alcoholics (1/6), people released from prison institutions (1\%), people with mental disorders (1\%). In terms of educational attainment, $45 \%$ had basic vocational education, $33 \%$ completed elementary education, $10 \%$ graduated from a vocational secondary school, $5 \%$ from a secondary grammar school, $3 \%$ had post-secondary education and 1\% completed higher education (MPS, 2005).

91. The proportions are according to the monitoring of five CIS undertaken by MPS (2005).

92. The integration allowance may top up the temporary social assistance benefit paid by social assistance centres. The costs of the integration allowances are refunded by a poviat starosta from Labour Fund resources. The CIS may receive advance payments for this purpose. 


\section{Box 4. Social Integration Centres (Cont.)}

The CIS clients are subject to regular evaluation of their performance. The first evaluation is undertaken at the end of the probation period, and the following ones are done on a six-month basis. Upon successful completion of the programme, and in justified cases even before its completion, ${ }^{93}$ the client may be referred ${ }^{94}$ to a supported employment ${ }^{95}$ or may be employed by the CIS. Some clients start self-employment activities. When there is no suitable work available, the client will return to the PUP or a social assistance centre.

Table 26 shows the status of CIS participants after completion of the programme. Participants who acquired qualifications in $\mathrm{CIS}$ do not have higher rates of employment in the open labour market. However, they did more often enter supported forms of employment. Interestingly, the CIS themselves preferred employing people with no qualifications rather than those who acquired qualifications in CIS. As they claim "for the work in CIS, qualifications have no great significance. What is most important is the mentality and enthusiasm for work. Thus the most significant result of CIS activities should be establishing a mentality of a worker rather than obtaining qualifications." (ISP, 2007).

Source: MPiPS (2003); ISP (2007); and MPiPS (2008a).

Table 25. Typical structure of CIS revenues, 2004

Percentages

\begin{tabular}{lccrr}
\hline \multicolumn{1}{c}{ Type of revenue } & $\begin{array}{c}\text { Self-government } \\
\text { CIS 1 }\end{array}$ & $\begin{array}{c}\text { Self-government } \\
\text { CIS 2 }\end{array}$ & $\begin{array}{c}\text { Civic } \\
\text { CIS 1 }^{1}\end{array}$ & $\begin{array}{c}\text { Civic } \\
\text { CIS 2 }^{\text {a }}\end{array}$ \\
\hline Labour Fund - Integration allowances & 6 & 21 & 0 & 2 \\
Gmina budget & 34 & 62 & 40 & 5 \\
Voivodeship budget & 11 & 11 & 1 & 20 \\
Subvention from MPiPS & 0 & 0 & 0 & 61 \\
Own CIS activities (production or trade) & 28 & 3 & 0 & 0 \\
Other - PHARE & 21 & 0 & 0 & 0 \\
Other - PARPA & 0 & 0 & 59 & 0 \\
Other - Grant from a foreign NGO & 0 & 3 & 0 & 0 \\
Total & $\mathbf{1 0 0}$ & $\mathbf{1 0 0}$ & $\mathbf{1 0 0}$ & $\mathbf{1 0 0}$ \\
\hline
\end{tabular}

a) Percentages in the column Civic CIS 2 do not total 100 in the original source.

Source: E. Leś, S. Nałęcz, Raport z monitoringu działania Centrów Integracji Społecznej 1,5 roku po uchwaleniu ustawy o zatrudnieniu socjalnym, PAN, Warszawa 2005, p. 20.

93. The CIS clients are never referred to a job before the completion of six months in the CIS.

94. Successful graduates from the programme are referred to jobs by a respective PUP based on the proposal of the CIS director, a social worker or the participant.

95. The agreement on the subsidised employment is concluded between the poviat starosta and the employer. According to the agreement the employer shall keep the participant in employment for a minimum period of 12 months for which he/she shall be refunded the participant's remuneration in the maximum amount of $100 \%$ of the unemployment insurance benefit together with social contributions (during the first three months), $80 \%$ of the unemployment insurance benefit together with social contributions (during the following three months), $60 \%$ of the unemployment insurance benefit together with social contributions (during the following six months). The same applies when the participant is employed by the CIS (MPiPS, 2003). 
Percentages

\begin{tabular}{lcc}
\hline \multicolumn{1}{c}{ Situation after programme completion } & No qualifications & Qualifications acquired in CIS \\
\hline Supported employment & 1.5 & 6.4 \\
Non-supported employment & 31.2 & 21.2 \\
Public works & 0.7 & 19.9 \\
Employed in CIS & 5.6 & 1.2 \\
Work in a social cooperative & 1.7 & 2.5 \\
Self-employment & 1.9 & 1.2 \\
Exit to work - Total & $\mathbf{4 2 . 6}$ & $\mathbf{5 2 . 4}$ \\
Unemployment & 40.4 & 40.8 \\
\hline
\end{tabular}

Source: ISP (2007).

149. Both CIS and KIS, like any other institution delivering services related to social inclusion, may compete for additional funds from the Ministry allocated in the framework of programmes such as "Active Forms of Counteracting Social Exclusion", "Supporting the Development of Social Cooperatives", and "Day-room, Job and Work Experience". The programme "Active Forms of Counteracting Social Exclusion" supports the operation of KIS and CIS, and the organisation of programmes of socially useful works ${ }^{96}$ as well as providing financial assistance to the best-performing non-governmental organisations providing social integration activities (MPiPS, 2006b). Within that programme, the Ministry in 2006 allocated PLN 900 thousand for KIS, i.e. PLN 15 thousand per institution (MPiPS, 2007h).

150. Currently the Polish Government has no intention of making the temporary benefit conditional on the employment activation of beneficiaries and their families. The effects of CIS treatment in terms of exits from welfare to work may serve as positive examples of intensive treatment based on mutual obligations approach. However, the sustainability of these outcomes and the cost-effectiveness of CIS approaches particularly the supported forms of employment should further be analysed.

96. In terms of gmina programmes of socially useful works, additional support from the Ministry is welcome as the Labour Fund only reimburses income support for the participants (i.e. $60 \%$ of all programme costs). Thus, in the gminas which received an allocation from the Ministry, $40 \%$ of people who were entitled to participate in the programme were actually admitted, which is much more than in the gmina that did not receive an allocation (MPiPS, 2007h). 


\section{REFERENCES}

\section{Documents cited in the main text}

Chloń-Domińczak, A. (2007), "Pension system and employment incentives - Polish experience", paper presented to at the International Forum on Pension Reform, Bled, Slovenia, 7-9 June (www.cefsee.org/pension_reform/ChlonDominczak.pdf).

CSO (Central Statistical Office) (2008a), Concise Statistical Yearbook of Poland 2007 (www.stat.gov.pl/gus/45_2144_ENG_HTML.htm).

CSO (2008b), “Employment in National Economy in 22007”, Warsaw (www.stat.gov.pl/cps/rde/xbcr/gus/PUBL_PDL_pracujacy_w_gospodarce_narodowej_w_2007.pdf).

European Commission (2005), "The new member states and local employment development: Taking stock and planning for the future. Poland country report", October.

Eurostat (2008), Labour market policy - expenditure and participants: Data 2006, Luxembourg. For years before 2006 see also online data "Public expenditure on labour market policies, by type of action" (http://epp.eurostat.ec.europa.eu - Data - Labour Market - Labour Market Policy).

ISP (Instytut Studiów Politycznych Polskiej Akademii Nauk, Institute of Political Studies of the Polish Academy of Sciences) (2007), E. Leś (ed), "Monitoring of the Act of 13 June 2004 on social employment. Research of the efficiency of social and occupational reintegration", Warsaw (in Polish).

Kalužná, D. (2008a), "Main Features of the Public Employment Service in the Slovak Republic", OECD Social, Employment and Migration Working Papers, No. 72, www.oecd.org/els/workingpapers.

Kalužná, D. (2008b), "Main Features of the Public Employment Service in the Czech Republic”, OECD Social, Employment and Migration Working Papers, No. 74, www.oecd.org/els/workingpapers.

MGiP (Ministerstwo gospodarki i pracy, Ministry of Economy and Labour) (2005), M. Bukowski (ed.) "Employment in Poland 2005", Warsaw.

MPiPS (Ministerstwo pracy i polityki spolecznej, Ministry of Labour and Social Policy) (2003), Act of 13 June 2003 on social employment (in Polish, excerpted and translated by the author).

MPiPS (2004a), Act of 20 April 2004 on Employment Promotion and Labour Market Institutions (in Polish). ${ }^{97}$

MPiPS (2004b), Act on Social Assistance (in Polish, translated by the author).

97. The Act in its original version (without current amendments) is also available in English (www.paiz.gov.pl/files/?id_plik=7318). 
MPiPS (2004c), Regulation of the Minister of Economy and Labour of 6 October 2004 on the employment boards (in Polish).

MPiPS (2004d), Regulation of the Council of Ministers of 28 September 2004 on the algorithm for determining the amounts of the Labour Fund resources for financing voivodeship tasks (in Polish).

MPiPS (2006a), “Information on the Labour Fund plan for 2007”, Warsaw (in Polish).

MPiPS (2006b), “Active Forms of counteracting social inclusion”, A programme operated by the Ministry of Labour and Social Policy, Warsaw (in Polish).

MPiPS (2006c), "Analysis of the situation in selected poviat labour markets and creation of the methodology of local labour market research in Poland", Warsaw (in Polish).

MPiPS (2007a), "Functional analysis of labour offices after their decentralisation to the self-government administration", Warsaw (in Polish).

MPiPS (2007b), "Information on the Labour Fund plan for 2008”, Warsaw (in Polish).

MPiPS (2007c), Responses of the Ministry for Labour and Social Policy to the Questionnaire on indicators of activation, Warsaw.

MPiPS (2007d), “Information on the institutional operation of the labour market", Warsaw (in Polish).

MPiPS (2007e), Regulation of the Council of Ministers of 2 March 2007 on the standards of the labour market services (in Polish).

MPiPS (2007g), “Annual report on granted forms of social assistance - Financial, in-kind and services in January-December 2006", Warsaw.

MPiPS (2007h), "Information on the implementation of assistance in active job search: Job clubs", Warsaw (in Polish).

MPiPS (2007i), Regulation of the Minister for Labour and Social Policy of 2 March 2007 on detailed conditions of delivering labour market services by public employment services (in Polish).

MPiPS (2007j), "Modern information solutions for improving the efficiency and efficacy of labour market and social security organisational units", Warsaw (in Polish).

MPiPS (2007k), "Poland: Labour market and social security - Macroeconomic performance in figures 1997-2006", Warsaw.

MPiPS (2007m), "Poland 2007: Report on the labour market and social security”, Warsaw (in Polish).

MPiPS (2008a), National strategy report on social protection and social inclusion 2008-2010, Warsaw.

MPiPS (2008b), Data provided by MPiPS on request in 2008 .

MPS (Ministerstwo polityki społecznej, Ministry of Social Policy) (2005), "Report from the monitoring of functioning of Social Integration Centres - 1.5 years after adopting the Act on social employment", Report prepared on the basis of a research realised by the Institute of political studies of the Polish Academy of Sciences, Warsaw (in Polish). 
OECD (2008), “Economic Survey of Poland, 2008 - Policy Brief”, June, OECD, Paris.

RWI (RWI Essen) (2005), "Study on the effectiveness of ALMPs". Research for the European Commission, DG Employment Social Affairs and Equal Opportunities, Essen.

Sultana, R. G. and A. G. Watts (2005), “Career Guidance in Europe's Public Employment Services: Trends and Challenges", Report prepared for the European Commission, DG Employment, Social Affairs and Equal Opportunities, Brussels.

WAW (Urzad pracy m. st. Warszawy, Labour Office of the Capital City of Warsaw) (2007), "Report of the Labour Office of the Capital City of Warsaw for 2007”, Warsaw (in Polish).

Wóycicka, I. (2005), "Poland. The implementation of the National Action Plan of Social Inclusion at Regional and Local Level", Report prepared for the European Commission, DG Employment and Social Affairs and Equal Opportunities, October.

Wóycicka, I. (2006), “Poland: Recent Developments, Active Inclusion and Minimum Resources”, Gdańsk.

www.mpips.gov.pl

www.psz.praca.gov.pl 


\section{BIBLIOGRAPHY}

\section{Sources and suggestions for further reading}

Bukowski, M. (ed.) (2005), Employment in Poland 2006. Productivity for Jobs, Warsaw.

Kietlińska, K., K. Piotrowska-Marczak, and B. Mikołajczyk (2007), "Economic Consequences of Changes in the Civic Society Institutions in Poland".

Kowalczyk, A. (2000), "Local Government in Poland", in T. Horváth (ed.), Decentralization: Experiments and Reforms - Local Governments in Central and Eastern Europe, Vol. 1, Budapest, (http://lgi.osi.hu/publications/books/decentralization/index.html).

MPiPS (2006), National Report on Strategies for Social Protection and Social Inclusion for 2006-2008, Warsaw.

MPiPS (2007), "Information on the Realization of Vocational Counselling in Labour Offices in 2006", Warsaw (in Polish).

Ringold, D. and L. Kasek (2007), "Social Assistance in the New EU Member States. Strengthening Performance and Labour Market Incentives", Washington, D.C: World Bank.

SEOR (2003), "The Role of National PESs in Processing Job Vacancies", A Report prepared for the European Commission, DG Employment and Social Affairs and Equal Opportunities, November.

MPS (Ministerstwo Polityki Spolecznej) (2005) Strategia Polityki Spolecznej na lata 2007-2013. (Strategy for Social Policy for 2007-2013) (www.mpips.gov.pl).

Surdej, A. (2004), "Managing Labour Market Reforms: Case Study of Poland”, Krakow.

UNDP (2007), “Education for Labour - Human Development Report Poland 2007”, Warsaw (in Polish).

UNDP (2006), "Social Exclusion and Integration in Poland - An indicators-based approach", Warsaw.

UNDP (2004), “Working Out Employment - Human Development Report Poland 2004”, Warsaw.

Vodopivec, M., A. Wörgötter and D. Raju (2003), "Unemployment Benefit Systems in Central and Eastern Europe: A Review of the 1990s", World Bank Social Protection Discussion Paper No. 310 (www.worldbank.org/referencel - documents and reports).

World Bank (2007), "Labour Markets in EU8+2: From the Shortage of Jobs to the Shortage of Skilled Workers", World Bank EU8+2 Regular Economic Report Part II Special Topic, September (www.worldbank.org/referencel - documents and reports).

www.gus.pl

www.ibngr.edu.pl

www.case.com.pl/

www.pfsl.pl/news.php?id=6\#h4_1 


\section{OECD SOCIAL, EMPLOYMENT AND MIGRATION WORKING PAPERS}

Most recent releases are:

No. 79 MANAGING HIGHLY-SKILLED LABOUR MIGRATION: A COMPARATIVE ANALYSIS OF MIGRATION POLICIES AND CHALLENGES IN OECD COUNTRIES

Jonathan Chaloff and Georges Lemaitre (2009)

No. 78 ACTIVATION POLICIES IN NORWAY

Nicola Duell, Shruti Singh and Peter Tergeist (2009)

No. 77 PENSION, PURCHASING-POWER RISK, INFLATION AND INDEXATION

Edward Whitehouse (2009)

No. 76 AN EVALUATION OF THE TAX-TRANSFER TREATMENT OF MARRIED COUPLES IN EUROPEAN COUNTRIES

Herwig Immervoll, Henrik Jacobsen Kleven, Claus Thustrup Kreiner and Nicolaj Verdelin (2009)

No. 75 ACTIVATION POLICIES IN IRELAND

David Grubb, Shruti Singh and Peter Tergeist (2009)

No. 74 MAIN FEATURES OF THE PUBLIC EMPLOYMENT SERVICE IN THE CZECH REPUBLIC Daniela Kaluzna (2008)

No. 73 LONG TIME-SERIES FOR PUBLIC EXPENDITURE ON LABOUR MARKET PROGRAMMES David Grubb and Agnès Puymoyen (2008)

No. 72 MAIN FEATURES OF THE PUBLIC EMPLOYMENT SERVICE IN THE SLOVAK REPUBLIC Daniela Kaluzna (2008)

No. 71 SOCIO-ECONOMIC DIFFERENCES IN MORTALITY

Edward Whitehouse and Asghar Zaidi (2008)

No. 70 INVESTMENT RISK AND PENSIONS: MEASURING UNCERTAINTY IN RETURNS Anna d'Addio, Jose Seisdedod and Edward Whitehouse (forthcoming)

No. 69 FILLING THE PENSION GAP: COVERAGE AND VALUE OF VOLUNTARY RETIREMENT SAVINGS Antolin, P. and Edward Whitehouse (2009) (forthcoming)

No. 68 THE IMPACT OF FOREIGN DIRECT INVESTMENT ON WAGES AND WORKING CONDITIONS Elena Arnal and Alex Hijzen (2008)

No. 67 THE DYNAMICS OF SOCIAL ASSISTANCE RECEIPT: MEASUREMENT AND MODELLING ISSUES, WITH AN APPLICATION TO BRITAIN

Lorenzo Cappellari and Stephen P. Jenkins

No. 66 REFORMING RETIREMENT-INCOME SYSTEMS: LESSONS FROM THE RECENT EXPERIENCES OF OECD COUNTRIES

John P. Martin and Edward Whitehouse (2008)

No. 65 THE JOINT DISTRIBUTION OF HOUSEHOLD INCOME AND WEALTH: EVIDENCE FROM THE LUXEMBOURG WEALTH STUDY

Markus Jantti, Eva Sierminska and Tim Smeeding (2008)

No. 64 A REVIEW OF STUDIES ON THE DISTRIBUTIONAL IMPACT OF CONSUMPTION TAXES IN OECD COUNTRIES

Neil Warren (2008)

Other series of working papers available from the OECD include: OECD HEALTH WORKING PAPERS 
DELSA/ELSA/WD/SEM(2009)8

\section{RECENT RELATED OECD PUBLICATIONS:}

PENSIONS AT A GLANCE - SPECIAL EDITION: ASIA/PACIFIC (2009)

GROWING UNEQUAL? Income Distribution and Poverty in OECD Countries (2008)

SICKNESS, DISABILITY AND WORK: BREAKING THE BARRIERS (VOL. 3) - DENMARK, FINLAND, IRELAND AND THE NETHERLANDS (2008)

JOBS FOR YOUTH: JAPAN (2008)

JOBS FOR YOUTH: CANADA (2008)

JOBS FOR YOUTH: NETHERLANDS (2008)

JOBS FOR YOUTH: NEW ZEALAND (2008)

JOBS FOR YOUTH: NORWAY (2008)

JOBS FOR YOUTH: UNITED KINGDOM (2008)

A PROFILE OF IMMIGRANT POPULATIONS IN THE $21^{\text {ST }}$ CENTURY (2008)

OECD EMPLOYMENT OUTLOOK (2008)

OECD LABOUR FORCE STATISTICS: 1987-2007 (2008)

INTERNATIONAL MIGRATION OUTLOOK - 2008 Edition

IMMIGRATION HEALTH WORKERS IN OECD COUNTRIES IN THE BROADER CONTEXT OF HIGHLY SKILLED MIGRATION (2008)

OECD REVIEWS OF LABOUR MARKET AND SOCIAL POLICIES IN SERBIA (2008)

JOBS FOR IMMIGRANTS (VOL. 2): Labour Market Integration in Belgium, France, The Netherlands and Portugal (2008)

MODERNISING SOCIAL POLICY FOR THE NEW LIFE COURSE (2007)

BABIES AND BOSSES - Reconciling Work and Family Life: A Synthesis of Findings for OECD Countries (2007)

BENEFITS AND WAGES - OECD Indicators (2007)

FACING THE FUTURE: KOREA'S FAMILY, PENSION AND HEALTH POLICY CHALLENGES (2007)

PENSIONS AT A GLANCE: Public policies across OECD countries (2007)

JOBS FOR YOUTH: KOREA (2007)

JOBS FOR YOUTH: BELGIUM (2007)

JOBS FOR YOUTH: SPAIN (2007)

JOBS FOR YOUTH: SLOVAK REPUBLIC (2007)

SICKNESS, DISABILITY AND WORK: BREAKING THE BARRIERS (VOL. 2) - AUSTRALIA, LUXEMBOURG, SPAIN AND THE UNITED KINGDOM (2007)

WOMEN AND MEN IN OECD COUNTRIES (2006)

For a full list, consult the OECD On-Line Bookstore at www.oecd.org 